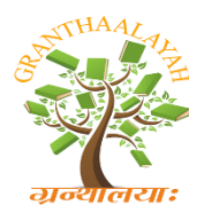

INTERNATIONAL JOURNAL OF RESEARCH GRANTHAALAYAH A knowledge Repository

Science

\title{
DOES THE HEALTH CARE PROVIDER FULFILL THE NEEDS AND EXPECTATIONS OF WOMEN DURING INTRA-PARTUM AND IMMEDIATE POSTPARTUM PERIOD IN A SELECTED GOVT. HOSPITAL OF WEST BENGAL?
}

\author{
Najnina Khatun ${ }^{1}$, Prof. Dr. Smritikana Mani ${ }^{2}$ \\ ${ }^{1}$ Sister in Charge IPGME\&R and SSKM Hospital, Kolkata-20, India \\ ${ }^{2}$ Principal, College of Nursing, Medical College \& Hospital, Kolkata-73, India
}

\begin{abstract}
A descriptive study was conducted to assess the needs and expectations and fulfilment of needs and expectations of intra-partum and immediate post partum women. The findings revealed that in the area of esteem need all women $(100 \%)$ wanted respectful maternity care. Intra-partum women had different types of need i.e. physiological need (92\%) personal and psychological need (90\%) social needs $(98.61 \%)$ and safety needs $(95 \%)$. Among various types of intra partum need $61.54 \%$ physiological needs were totally fulfilled. Pain relieving needs of immediate postpartum women were totally fulfilled (100\%). Statistically significant association were found between educational status and fulfilment of personal \& psychological need $(\chi 2=5.257)$ and gravida and fulfilment of informational needs $(\chi 2=14.920)$ at $\mathrm{df} 1, \mathrm{p}<0.05$ level of significance. There was a moderate negative correlation (' $r$ ' $=-0.548$ ) found between gravid and intra partum and immediate postpartum needs. There was a significant mean difference $(\mathrm{t}=5.399$, at $\mathrm{df} 118)$ between fulfilment of needs of primigravida and multigravida women at 0.05 level of significance. The study has a implication in nursing service by assessing the needs \& expectations of intra partum and immediate postpartum women, the total needs can be fulfilled by health care provider.
\end{abstract}

Keywords: Needs; Expectations; Fulfilment; Health Care Provider.

Cite This Article: Najnina Khatun, and Prof. Dr. Smritikana Mani. (2019). "DOES THE HEALTH CARE PROVIDER FULFILL THE NEEDS AND EXPECTATIONS OF WOMEN DURING INTRA-PARTUM AND IMMEDIATE POSTPARTUM PERIOD IN A SELECTED GOVT. HOSPITAL OF WEST BENGAL?.” International Journal of Research - Granthaalayah, 7(10), 104-145. https://doi.org/10.29121/granthaalayah.v7.i10.2019.380.

\section{Introduction}

Normal labour is a spontaneous process of expulsion of the foetus and placenta. However, it is important to remember that the intra-partum and immediate postpartum women have some different kind of needs. Health care provider has the responsibility to assess the needs and provide 
care to women according to their needs. The first 48 hours after delivery are the most critical in the entire post-partum period. During this time they are not able to take care of self. They are suffering from pain at abdomen, episiotomy suturing. They are hungry, tired and fatigued. They are not able to take care of newborn baby also.

\subsection{Background of the Study}

Pregnancy and birth are unique processes for women. Women hold different needs and expectations during child bearing based on their knowledge, experiences, and belief systems, cultural, social and family backgrounds. These differences should be understood and respected, and care is adapted and organized to meet the individual needs of women 1.

Satisfaction of the patient is crucial for maintaining and monitoring the quality of health care and can inform service development and delivery. Intra-partum satisfaction is a broad, multifaceted concept that includes experiences of the women during labour, birth and immediate postpartum period. Satisfaction in this context is often about giving birth in a manner that matches the needs of every woman 2 .

The postpartum period is the time which reflects the approximate time required for uterine involution and return of most maternal body systems to a non-pregnant state. During this period physical recovery takes place as well as the women has to meet the needs of an infant. Evidences suggested that if these needs are unmet the stressors of the postpartum period can lead to anxiety, physical and mental illness3.

Women were dissatisfied with intra partum care. Mohammad K, Shaban I, Homer C, Creedy D2 conducted a study that support these findings. Data showed that the total mean satisfaction score with intra-partum care was $36.12(\mathrm{SD} \pm 8.88)$. They considered the score of $\geq 45$ were positive towards increased satisfaction with intra-partum care. In this study only $17.8 \%(n=53)$ of the participants scored $\geq 45$ and $82.2 \%(n=245)$ women scored lower suggesting dissatisfaction with the intra-partum care, $13 \%$ of women were satisfied with interpersonal care, in the area of information sharing and in making decision is $20.5 \%$ and whereas only $18.8 \%$ in physical birth environment.

A study also conducted on Chinese expectant parents by Zhang X and Lu H4. They tried to explore expectations regarding childbirth showed that the expectant parents had a high level expectations regarding childbirth in the area of care giving environment, spousal support, control and participation and medical support. Conversely their expectations towards labour pain and their own ability to cope with the pain were low. There were two predictors of expectant mothers' regarding childbirth expectations i.e. expectant fathers' expectations and partner's accompany as support person explaining $18.9 \%$ and $3.3 \%$ of the total variance respectively.

\subsection{Need of the Study}

Pregnancy and childbirth are important moments in the lives of pregnant women. Giving birth is the most special and memorable moment in a woman's life. Women always remember their labour experience and often find it very positive and enjoyable. But some women may have bad, 
frightening childbirth experiences and they are quite anxious about this1. So understanding women's need during intra-partum and immediate postpartum period is one of the first steps to help and support women to achieve the most satisfying experience.

Dr. Abdel GR, and Dr. Berggren V5 conducted a study on parturient needs during labour of Egyptian women. They identified twenty-two needs from the women's perspective. Among all of these needs the highest ranked needs for these women during labour were maintaining privacy through all procedures (86.5\%), accessibility of nurses to demonstrate empathy (67.5\%), availability to ventilate their feelings, fear and anxiety (57.5\%), quick response on calling (67.5\%), frequent monitoring (52.8\%), accessibility of caring medical staff (47.2\%) and short delivery $(52.8 \%)$.

So, the investigator, by doing this research tries to help the women by identifying the needs and expectations during intra-partum and immediate postpartum period and helps to provide quality care to the women.

So, the investigator selected the study on does the health care provider fulfil the needs and expectations of women during intra-partum and immediate postpartum period in a selected Govt. hospital, West Bengal.

Purpose: The purpose of the study is to assess the care provided by the health care provider to fulfill the needs and expectations of women during intra-partum and immediate postpartum period. Problem Statement: Does the health care provider fulfil the needs and expectations of women during intra-partum and immediate postpartum period in a selected Govt. hospital of West Bengal?

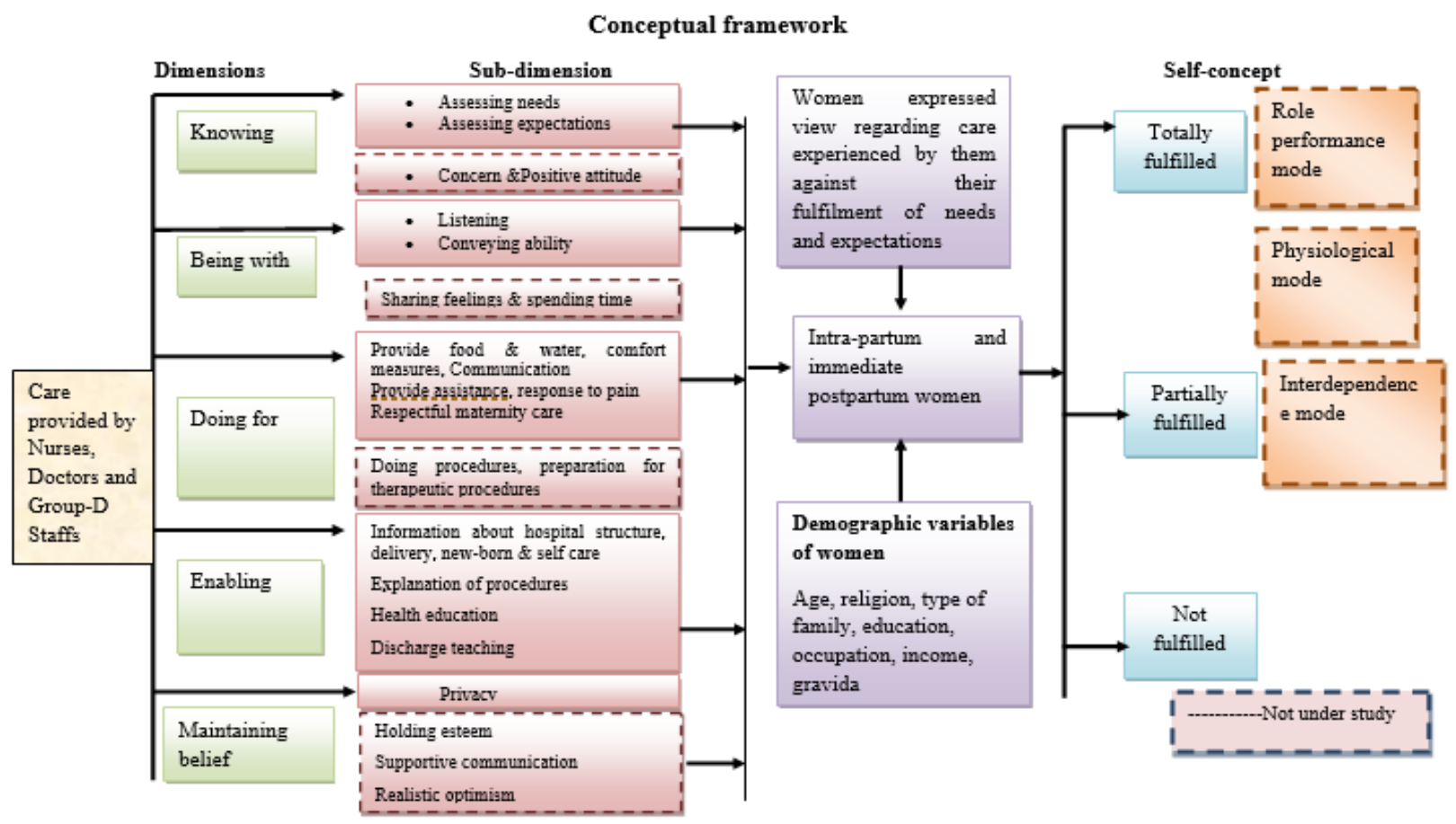

Figure 1: Conceptual framework based on Swanson's Theory of caring and Roy's Adaptation Model 


\subsection{Literature Related to Needs of Intra-Partum Women}

Panda S, D'Sa J. and Rao AC6 conducted a descriptive study. The mean percentage distributions of scores under physical support needs were highest in needs (100\%) as well as support (100\%) for maintenance of hygiene and were lowest in needs (49.33\%) in positioning and need for support $(52.33 \%)$ in maintenance of hydration during labour.

A descriptive exploratory qualitative study was conducted by Iravani M, Zarean E, Janghorbani M, and Bahrami1 M. Study findings expressed that intervening to promote physiological needs can positively influenced on the women's sense of control and empowers during birthing. Some women were disappointed of restriction of eating and drinking during labour.

An analytic-cross sectional study was conducted by Dr Abdel GR and Dr Berggren V5 showed that twenty two need requirements emerged from women's perspective. $86.5 \%$ of women reported their needs for maintaining privacy through all procedure, $67.5 \%$ reported a need for qualified nurses offer help and demonstrate empathy.

A thorough systemic review was carried out by Iliadou M7 to identify practical points for supporting women in labour. Women during labour have a strong need for companionship, empathy and help. Continuous support appears to have a greater beneficial impact than intermittent support. Women's expectations of labour as a whole appear to be of more importance to their overall satisfaction with their labour experience than the perceived effectiveness of pain management.

\subsection{Literature Related to Women's Expectations in Labour.}

Zhang $\mathrm{X}$ and Lu H4 conducted a study on childbirth expectations. The total mean score of Childbirth Expectations Questionnaire was 4.14(SD=0.33) expectant mothers and 4.15(SD=0.30) for expectant fathers, revealed that couple's perceived a high level of childbirth expectations towards caring environment, spousal support, control and participation and medical support. Their expectations toward labour pain and their coping ability were relatively negative $(\mathrm{M} 1=2.34$, $\mathrm{SD} 1=0.67 ; \mathrm{M} 2=2.46, \mathrm{SD} 2=0.65)$.

Pirdel M and Pirdel L8 conducted a descriptive-comparative study to compare women's expectations and experiences of childbirth. In the two groups, there was a negative significant relationship between the expectation and experience of childbirth in primiparas $(r=-0.62, p<0.001)$ and multiparas $(\mathrm{r}=-0.69, \mathrm{p}<0.001)$.

\subsection{Literature Related to Needs and Expectation of Postpartum Women}

Lindberg I, Ohrling K and Christeensson K9 presented a study that showed that expectations of care in the maternity ward were 'the wish to have access to staff on the maternity ward' $(99.3 \%)$, to have support during breastfeeding $(90.6 \%)$, to have the family staying on the maternity ward $(86.3 \%)$, and to have information about breastfeeding (85.4\%) infant behaviour (82\%) and childcare $(82.7 \%)$. 


\section{Research Methodology}

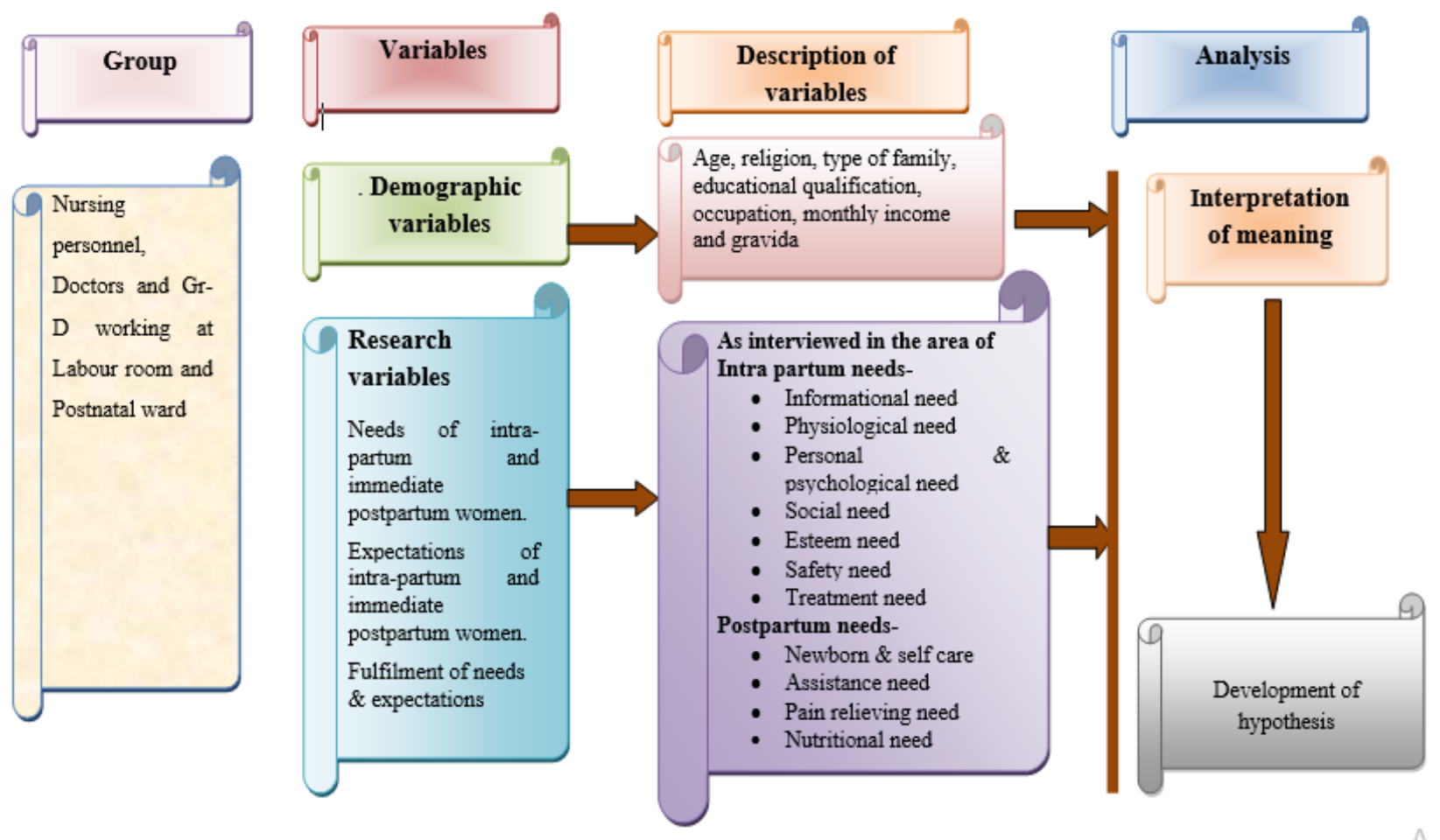

Figure 2: schematic presentation of descriptive research design

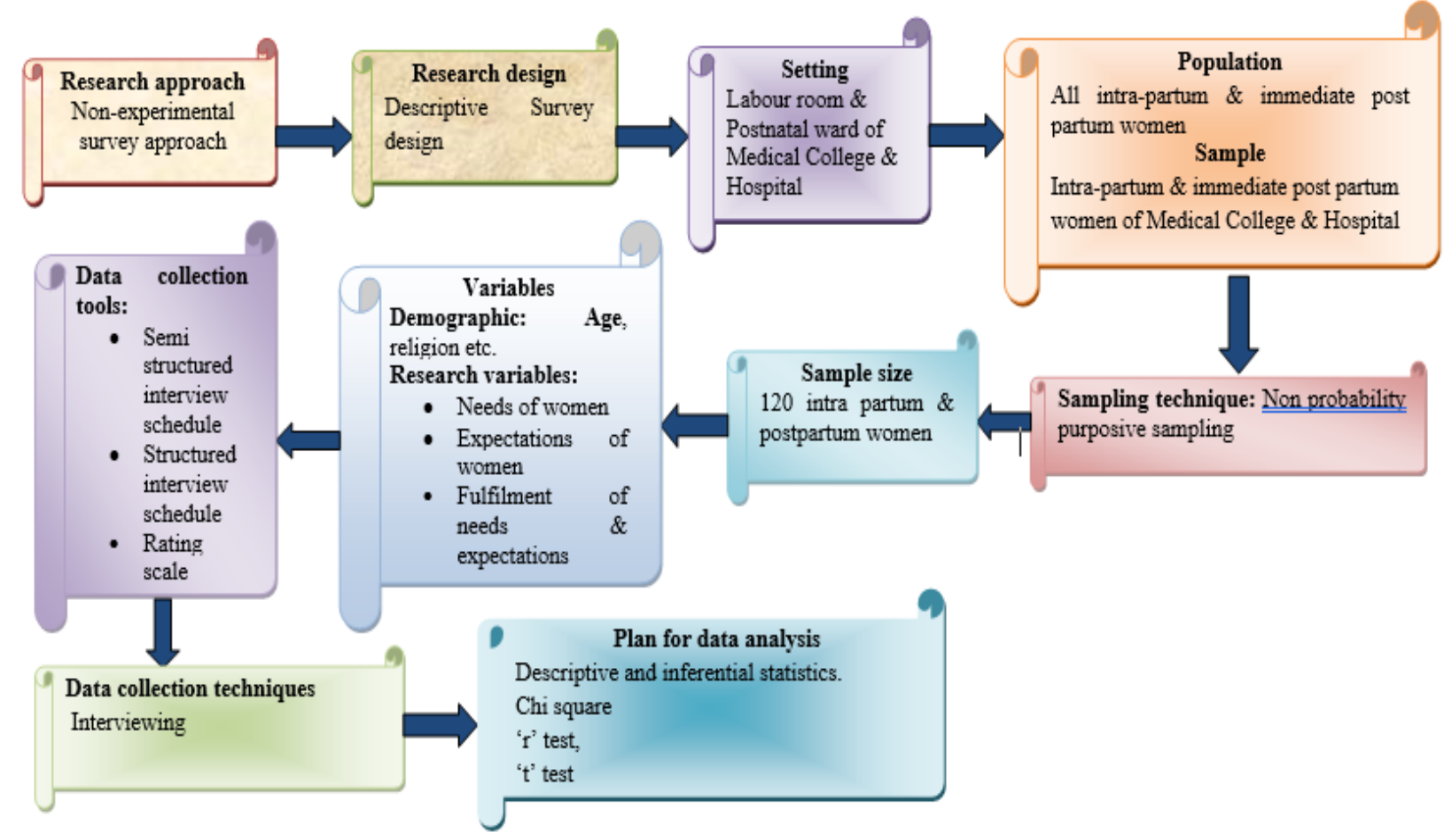

Figure 3: Schematic diagram of research methodology 


\section{Variables Under Study}

\section{Research variables}

Needs of intra-partum and immediate postpartum women

Expectations of intra-partum and immediate postpartum women

Fulfilment of needs and expectations.

Demographic variables: Age, religion, gravida, education, family income, occupation of women, type of family.

\section{Population}

Population for the present study were all intra-partum and immediate postpartum women of West Bengal.

\section{Sampling Technique}

Non- probability purposive sampling technique was adopted for study .

\section{Reliability of the Tool}

Reliability of semi structured interview schedule for identification of the needs and expectations was computed by Kuder Richardson formula 20 method and reliability was 0.92 . Reliability of 3 point Rating scale is established by Cronbach's alpha reliability method and the reliability was found 0.94 .

\section{Final Study}

Final study conducted from 15.10.2018 to 24.11.2018. The investigator herself collected the data. After obtaining formal administrative permission from concerning authorities subjects were selected according to the inclusion criteria by using non-probability purposive sampling technique. Self-introduction was given to the subjects and established rapport with them. Explained the purpose of the study to the subjects and addressed the terms of confidentiality. Then informed consent for the study was obtained from the subjects. Separate code number was given to each subject. At first demographic data collected from the intra partum women. Then needs and expectations during intra-partum and immediate postpartum period were assessed by using semi structured interview schedule at observation room of Labour room from the women. After normal vaginal delivery the women were sent to postnatal ward. The investigator again collected data to assess the care provided by the health care provider to fulfil the needs and expectations from the women as they felt by introducing 3 point rating scale at postnatal ward at the time of discharge. After collecting the data investigator left the subjects with thanks. Total time taken for one interview was approximate 25 minutes at intra partum period and 20 minutes at immediate postpartum period.

\section{Plan for Data Analysis}

Plan for data analysis was planned to analyse by using descriptive and inferential statistics. Data were analysed by using percentage frequency and chi square. Bar, Pie diagram and table were used to represent the demographic characteristics of women. Intra partum and immediate post partum needs were represented through bar, cone and column diagram separately for every area. Fulfilment of needs and expectation of intra partum and immediate postpartum women were represented through cone diagram and pie diagram respectively. Chi-square and Correlation coefficient test were computed to find the association between selected demographic variables and fulfilment of needs. Unpaired ' $t$ ' test was computed to find out the significant difference of mean score of primigravida and multigravida on needs fulfilment. 


\section{Analysis and Interpretation}

Table 1: Sample Characteristics

\begin{tabular}{|l|l|l|}
\hline Demographic Variables & Frequency & Percentage (\%) \\
\hline Age & 114 & 95 \\
18-28 years & 6 & 5 \\
29-38 years & 0 & 0 \\
>39 years & & \\
\hline Religion & 50 & 41.66 \\
Hindu & 70 & 58.33 \\
Muslim & 0 & 0 \\
Others & & \\
Type of family & 70 & 58.33 \\
Nuclear & 50 & 41.66 \\
Joint & 0 & 0 \\
Extended & 15 & 12.5 \\
Educational Status & 21 & 17.5 \\
Illiterate & 57 & 47.5 \\
Primary & 27 & 22.5 \\
Madhyamik & & \\
H.S \& above & 116 & 96.66 \\
\hline Occupation & 1 & 0.83 \\
Housewife & 3 & 2.5 \\
Businessmen & & \\
Service & 49 & 40.83 \\
\hline Income of the family & 22 & 18.33 \\
<Rs 2000/- & 43 & 35.83 \\
Rs 2001-5000/- & 61 & 5 \\
Rs 5000-10000/- & 39 & 67.5 \\
> Rs 10000/- & & 32.5 \\
Gravida & & \\
Primigravida & & \\
Multigravida & & \\
& & \\
\hline
\end{tabular}

The data presented in the Table 1 depicts that most of women (95\%) belongs to 18-28 years of age group, $58.33 \%$ women are Muslim \& belong to nuclear family, maximum women were educated up to madhyamik (47.50\%), most of $(96.66 \%)$ women were housewife, Maximum family $(40.83 \%)$ earned less than 2000 rupees and $67.5 \%$ women were primigravida. 


\section{Informational needs}

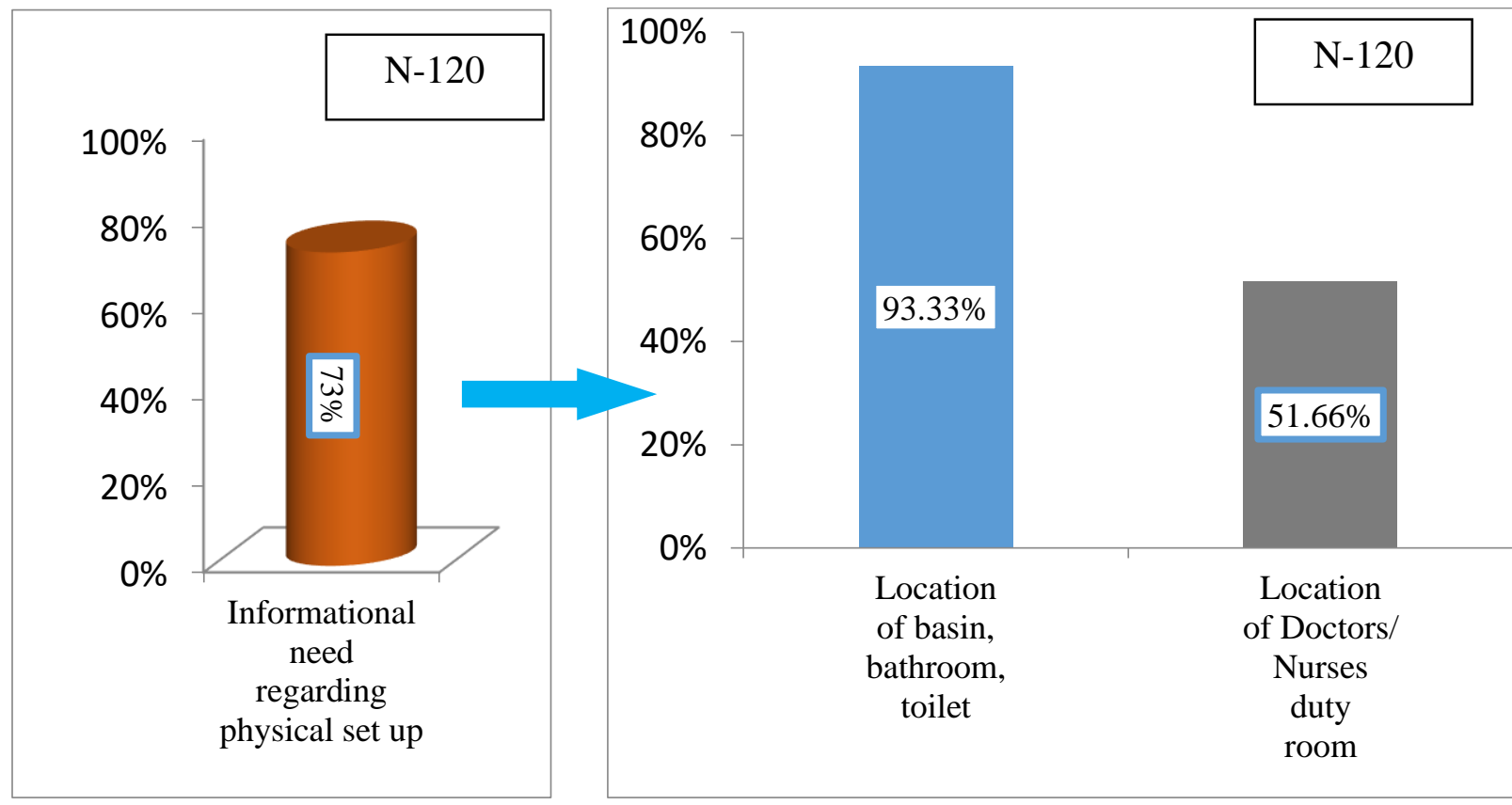

Figure 4: Bar diagram showing percentage distribution of different informational needs regarding physical set up of intra-partum women.

Data presented in figure-4 depicts that majority (73\%) of women asked information about physical set up of ward. Among them most of women (93.33\%) wanted information about location of basin, bathroom, toilet and only $51.66 \%$ women wanted to know where was the doctors and nurses duty room.

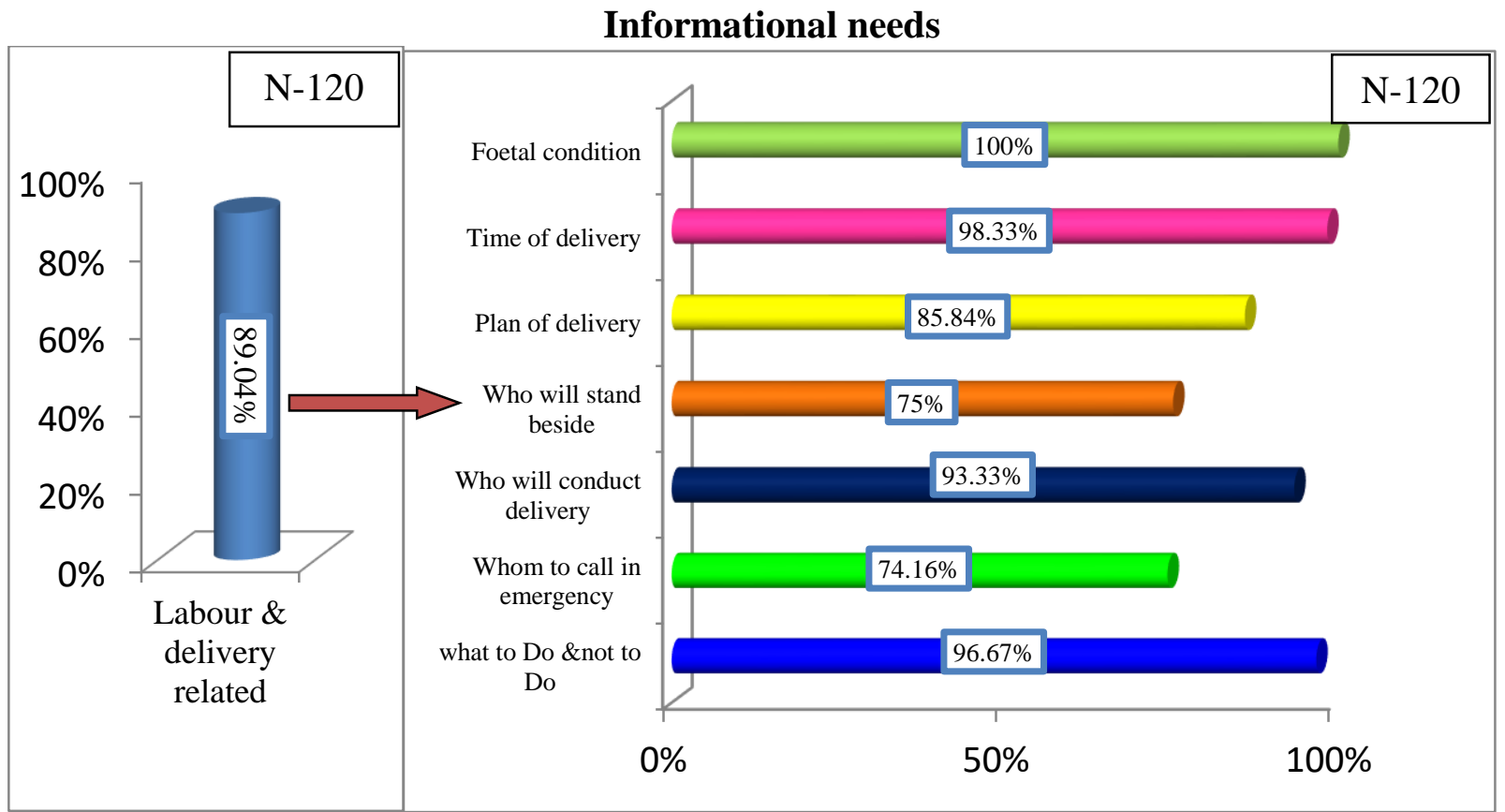

Figure 5: Bar diagram showing percentage distribution of different informational needs related to labour \& delivery of intra-partum women. 
Data presented in fig-5 represents that most $(89.04 \%)$ of the women wanted to know labour \& delivery related information. But all women wanted information about foetal condition and most of the women wanted information about time of delivery $(98.33 \%)$, who will conduct delivery $(93.33 \%)$, what to do \& not to do $(96.67 \%)$, and majority of women wanted to know who will stand beside $(75 \%)$ and whom to call in emergency $(74.16 \%)$.

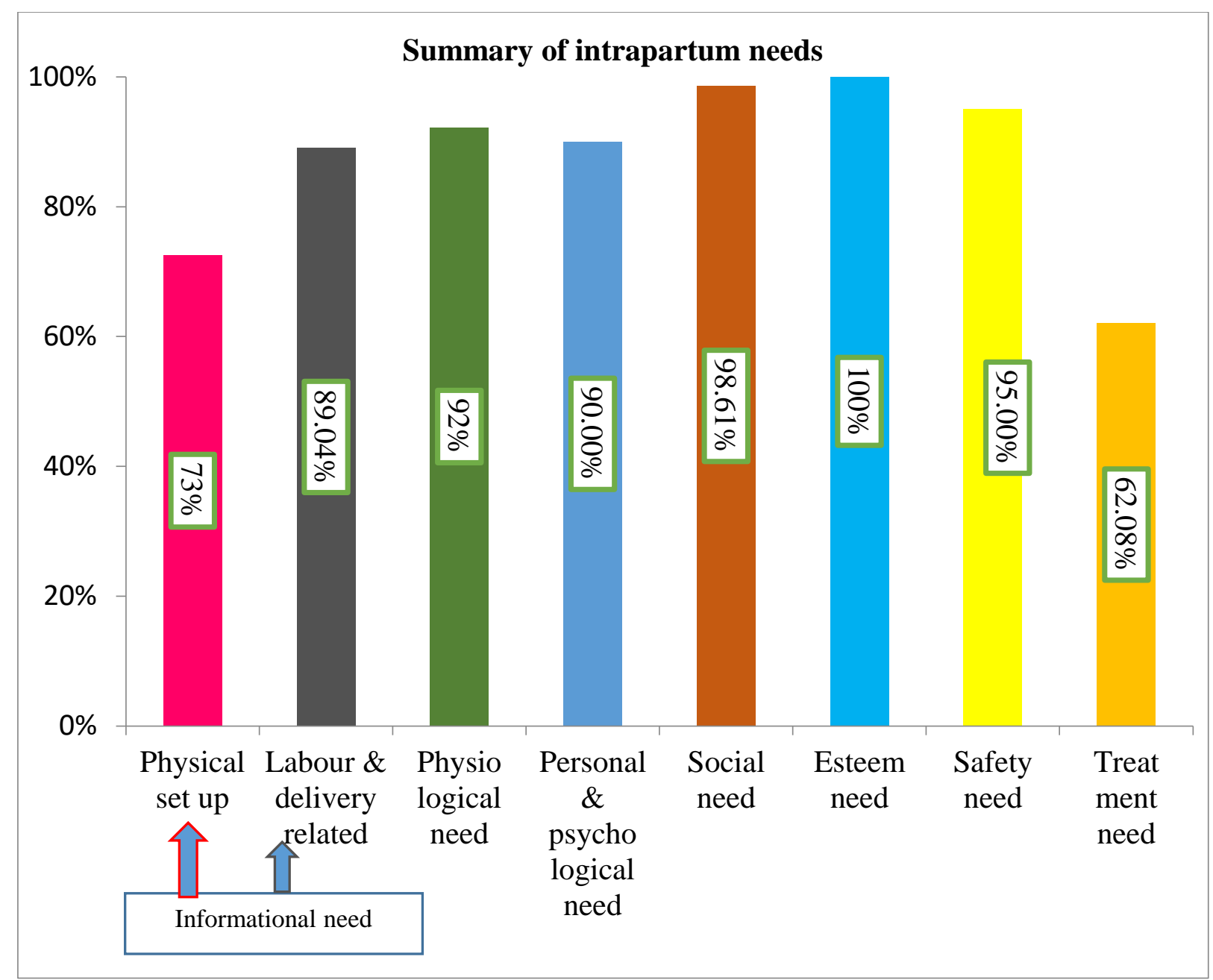

Figure 6: Bar diagram showing percentage distribution of different intra partum needs.

Data presented in figure 6 multiple bar diagram shows that all women (100\%) have esteem need. Most of the women had informational needs regarding physical set up (73\%), and labour \& delivery related $(89.04 \%)$, physiological need $(92 \%)$, personal and psychological need $(90 \%)$, social need $(98.61 \%)$, safety need $(95 \%)$ and majority of women had treatment need (62\%). 


\section{Informational needs about Newborn care}

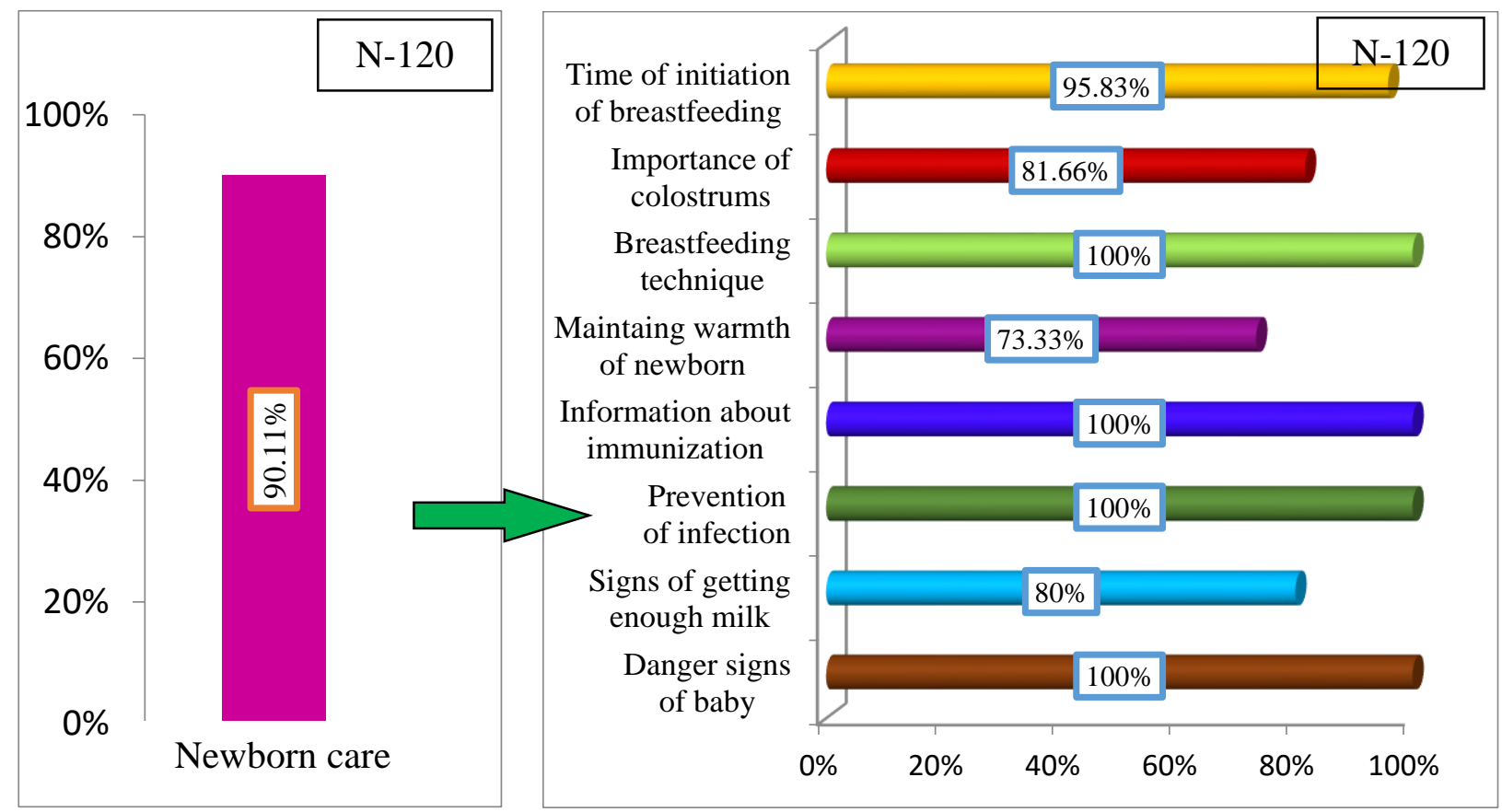

Figure 7: Bar diagram showing different percent distribution of informational needs about newborn care of immediate postpartum women.

Data presented in figure-7 shows most $(90.11 \%)$ of women wanted information about newborn care. Among them all women asked about baby care like breastfeeding technique, immunization, prevention of infection and danger signs of baby. Most of the women (95.83\%) wanted to know the time of initiation of breast milk. Majority of women wanted to know about importance of colostrums (81.66\%), how to maintain warmth of newborn $(73.33 \%)$, signs of getting enough milk $(80 \%)$.

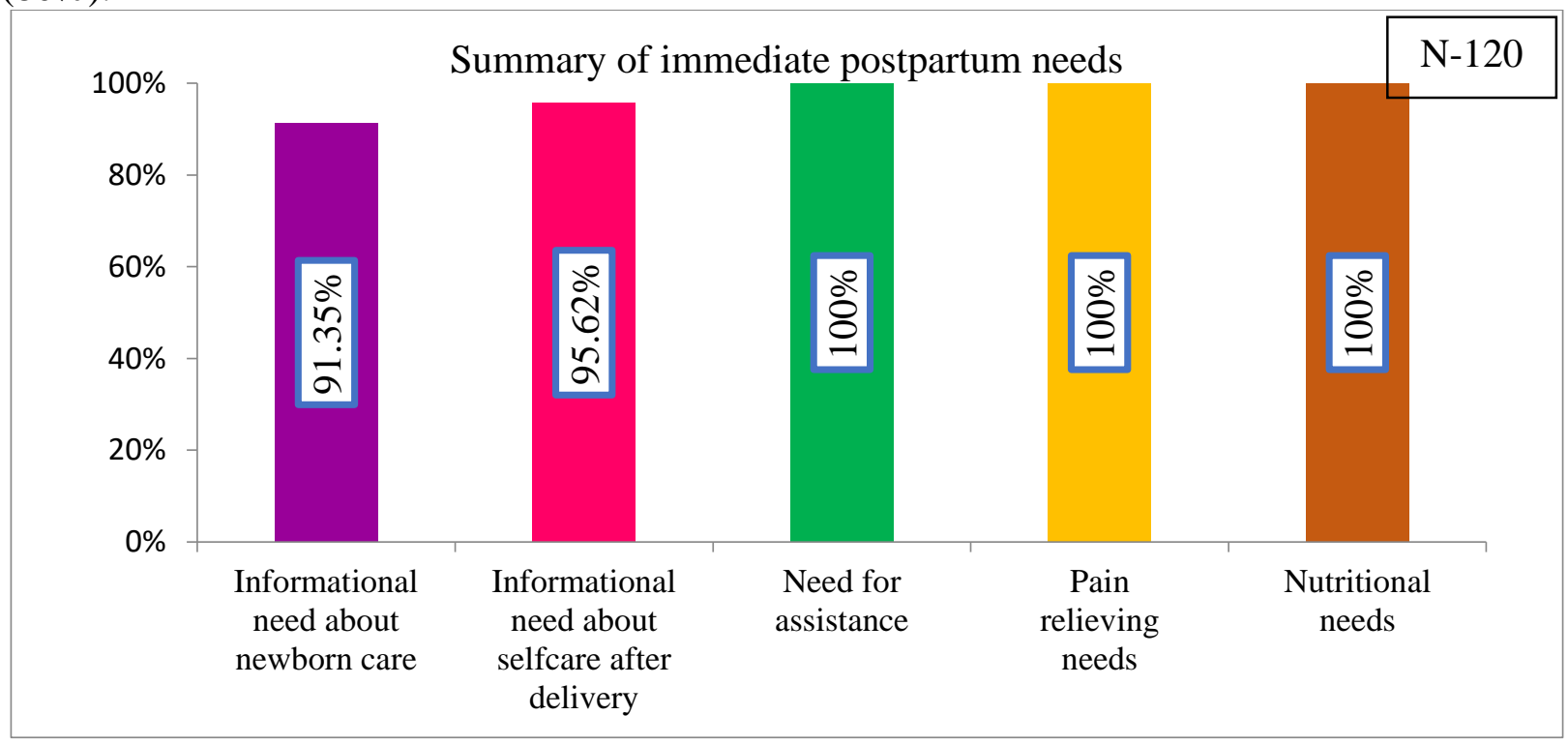

Figure 8: Bar diagram depicting percentage distribution of different needs of women during immediate postpartum period. 
Data presented in the figure- 8 shows that all women had need for assistance, pain reliving and nutritional needs. Most of the women wanted information about newborn care $(91.35 \%)$ and self care $(95.62 \%)$ after delivery.

Summary of Intra-partum needs \& expectations fulfillment

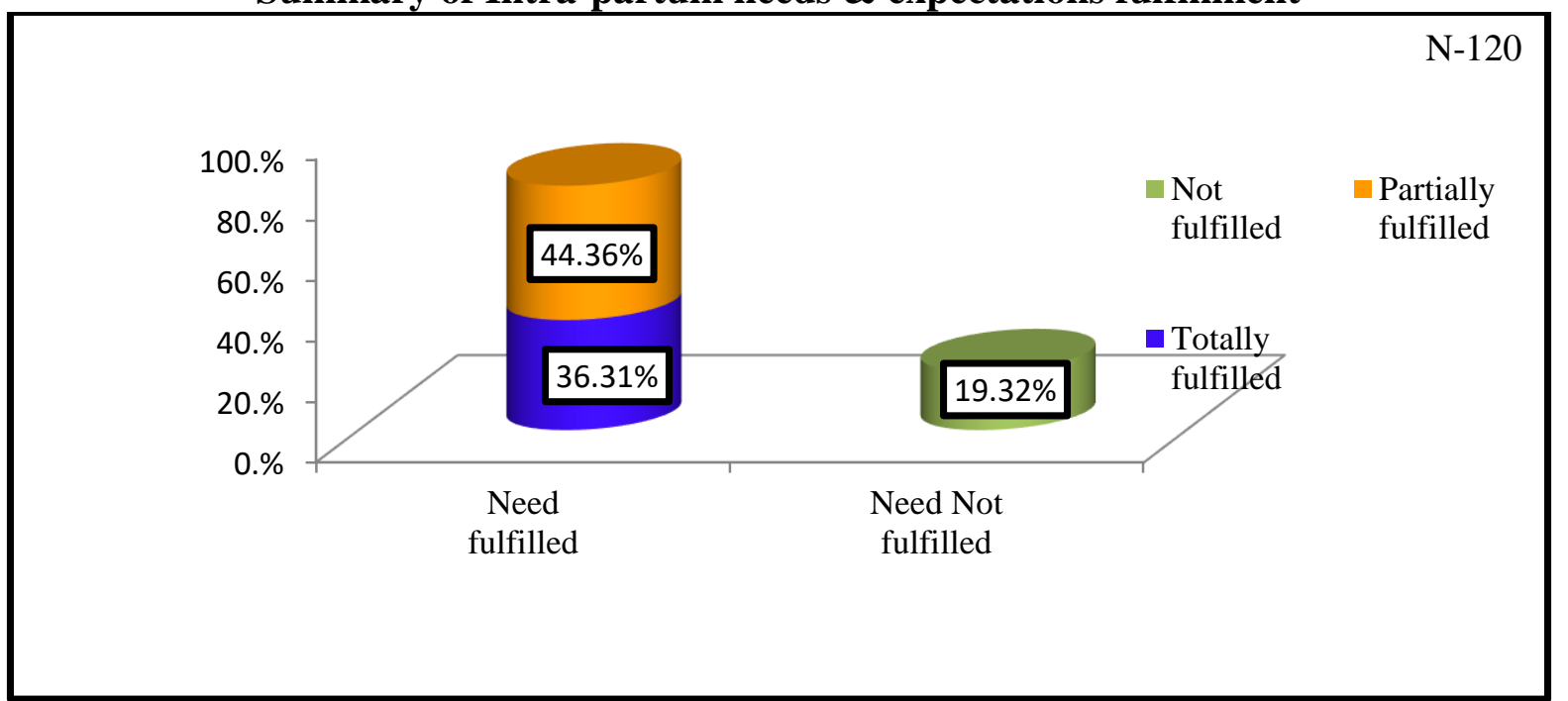

Figure 9: Cylinder diagram depicting percentage distribution of intra-partum needs and expectations according to fulfilment. Data presented in figure 22 depict that maximum (44.36\%) intra-partum needs \& expectations were partially fulfilled and only $19.32 \%$ needs were not fulfilled.

Summary of fulfillment of immediate postpartum needs and expectations

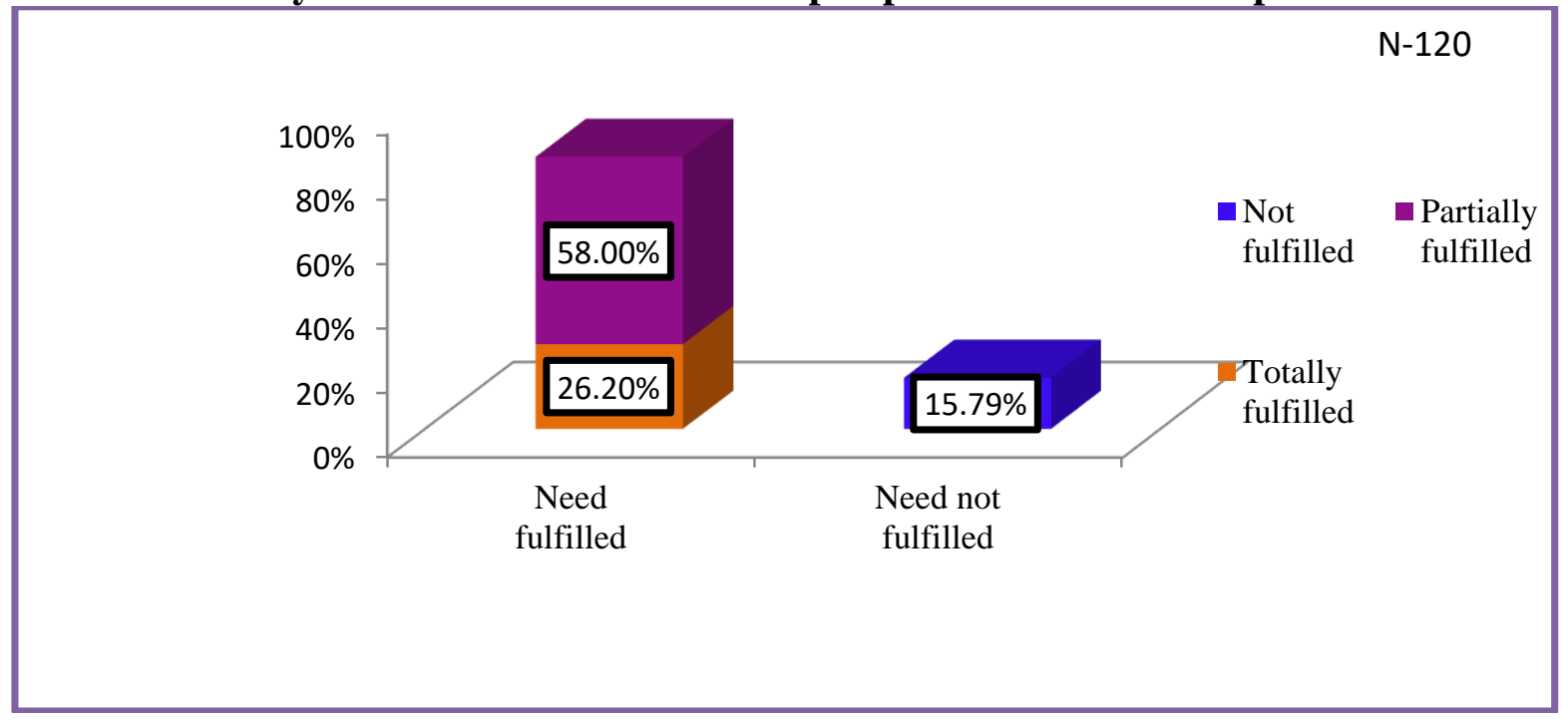

Figure 10: Column diagram depicting percentage distribution of postpartum needs and expectations according to fulfilment. Figure 23 presented data show that maximum needs \& expectations $(58 \%)$ during immediate postpartum period were partially fulfilled 
Table 2: Association between educational status and intra partum needs, fulfillment of needs during intra partum period

\begin{tabular}{|c|c|c|c|c|c|c|c|}
\hline \multirow[t]{2}{*}{$\begin{array}{c}\text { Demographic } \\
\text { variables }\end{array}$} & \multicolumn{2}{|c|}{$\begin{array}{c}\text { Intra partum } \\
\text { needs }\end{array}$} & \multirow[t]{2}{*}{$\chi^{2}$} & \multirow[t]{2}{*}{$\begin{array}{c}\text { Fishers } \\
\text { exact }\end{array}$} & \multicolumn{2}{|c|}{$\begin{array}{c}\text { Fulfillment of intra } \\
\text { partum needs }\end{array}$} & \multirow[t]{2}{*}{$\chi^{2}$} \\
\hline & Present & Absent & & & Fulfilled & $\begin{array}{c}\text { Not } \\
\text { fulfilled }\end{array}$ & \\
\hline \multirow[t]{7}{*}{ Education } & \multicolumn{2}{|c|}{$\begin{array}{c}\text { Informational } \\
\text { needs }\end{array}$} & & & & & \\
\hline & 4 & 11 & 0.119 & - & 8 & 7 & 0.004 \\
\hline & 20 & 85 & & & 57 & 48 & \\
\hline & \multicolumn{2}{|c|}{ Physiological needs } & & & & & \\
\hline & 6 & 9 & 1.074 & - & 7 & 8 & 0.119 \\
\hline & 57 & 48 & & & 54 & 51 & \\
\hline & \multicolumn{2}{|c|}{$\begin{array}{l}\text { Personal \& } \\
\text { psychological need }\end{array}$} & & & & & \\
\hline Illiterate & 9 & 6 & 0.019 & - & 2 & 13 & $5.257^{*}$ \\
\hline \multirow[t]{10}{*}{ Literate } & 61 & 44 & & & 51 & 54 & \\
\hline & \multicolumn{2}{|c|}{ Social need } & & & \multicolumn{2}{|c|}{ Esteem need } & \\
\hline & 15 & 0 & - & 1.0 & 8 & 7 & 2.283 \\
\hline & 100 & 5 & & & 35 & 70 & \\
\hline & \multicolumn{2}{|c|}{ Safety need } & & & & & \\
\hline & 14 & 1 & 0.336 & - & 7 & 8 & 0.119 \\
\hline & 88 & 17 & & & 54 & 51 & \\
\hline & \multicolumn{2}{|c|}{ Treatment need } & & & & & \\
\hline & 4 & 11 & 0.0 & - & 8 & 7 & 0.875 \\
\hline & 24 & 81 & & & 69 & 36 & \\
\hline
\end{tabular}

With Yates correction $\chi^{2}$ value at $\mathrm{df}(1)=3.84, \mathrm{p}<0.05$, * significant With Fisher's Exact Test, $\mathrm{p}>0.05$ at df (1)

The data presented in the table 2 reveal that there is no significant association between education and informational $(\chi 2=0.119)$, physiological $(\chi 2=1.074)$, personal \& psychological $(\chi 2=0.019)$, safety $(\chi 2=0.336)$ and treatment need $\left(\chi^{2}=0.0\right)$ and social need as the obtained $p$ value 1.0 through Fisher's Exact test at df 1 at 0.05 level of significance.

However there is significant association found between education and fulfillment of personal \& psychological as evident from $\chi^{2}$ value 5.257 and no association found between education and fulfillment of informational $(\chi 2=0.004)$, physiological $(\chi 2=0.119)$, esteem $\left(\chi^{2}=2.283\right)$, safety $(\chi 2=0.119)$ and treatment need $(\chi 2=0.875)$ at $\mathrm{df} 1$ at 0.05 level of significance. 
Table 3: Association between educational status and immediate postpartum needs, fulfillment of needs during immediate postpartum period.

\begin{tabular}{|c|c|c|c|c|c|c|}
\hline \multirow[t]{2}{*}{$\begin{array}{l}\text { Demographic } \\
\text { variables }\end{array}$} & \multicolumn{2}{|c|}{$\begin{array}{c}\text { Immediate postpartum } \\
\text { needs }\end{array}$} & \multirow[t]{2}{*}{$\chi^{2}$} & \multicolumn{2}{|c|}{$\begin{array}{l}\text { Fulfillment of immediate } \\
\text { postpartum needs }\end{array}$} & \multirow[t]{2}{*}{$\chi^{2}$} \\
\hline & Present & Absent & & Fulfilled & Not fulfilled & \\
\hline Education & \multicolumn{2}{|c|}{$\begin{array}{l}\text { Informational needs } \\
\text { regarding newborn care }\end{array}$} & & & & \\
\hline & 10 & 5 & 0.090 & 8 & 7 & 0.317 \\
\hline & 74 & 31 & & 64 & 41 & \\
\hline & \multicolumn{2}{|c|}{$\begin{array}{l}\text { Informational needs } \\
\text { regarding self care }\end{array}$} & & & & \\
\hline Illiterate & 13 & 2 & 0.008 & 8 & 7 & $3.883^{*}$ \\
\hline \multirow[t]{8}{*}{ Literate } & 86 & 19 & & 81 & 24 & \\
\hline & \multicolumn{2}{|l|}{-} & & \multicolumn{2}{|c|}{ Assistance need } & \\
\hline & & & & 10 & 5 & 1.544 \\
\hline & & & & 52 & 53 & \\
\hline & \multicolumn{2}{|l|}{-} & & \multicolumn{2}{|c|}{ Nutritional need } & \\
\hline & & & & 10 & 5 & 0.503 \\
\hline & & & & 79 & 26 & \\
\hline & & & & & & \\
\hline
\end{tabular}

$\chi 2$ value at $\mathrm{df}(1)=3.84, \mathrm{p}<0.05, *$ significant

The data presented in the table 3 reveal that there is no significant association between education and informational need regarding newborn care $\left(\chi^{2}=0.090\right)$ and self care $\left(\chi^{2}=0.008\right)$ at df 1 at 0.05 level of significance.

However there is significant association between education and fulfillment of informational need regarding self care as evident from $\chi^{2}$ value 3.883 and no association found between education and fulfillment of informational need regarding newborn care $\left(\chi_{2}=0.317\right)$, assistance need $\left(\chi^{2}=\right.$ $1.544)$ and nutritional need $(\chi 2=0.503)$ at $\mathrm{df} 1$ at 0.05 level of significance.

Table 4: Correlation coefficient ' $r$ ' showing relationship

\begin{tabular}{|l|l|l|l|}
\hline Variables & Mean & r & Remarks \\
\hline Gravida & 1.325 & -0.5483 & Significant \\
Intra partum and immediate postpartum needs & 52.933 & & \\
\hline
\end{tabular}

$\mathrm{N}-120$

At df (118) ' $r$ ' value $0.174, p<0.05$ level of significance

Data presented in table 4 shows that there is moderate negative correlation between gravida and intra partum and immediate postpartum needs. It may be due to their experience. The relationship is statistically significant at 0.05 level of significance. 
Table 5: Unpaired t-test

$\mathrm{N}-120$

\begin{tabular}{|l|l|l|l|l|l|}
\hline Gravida & Mean score of needs fulfillment & MD & SDD & SE$_{M D}$ & “t”-value \\
\hline Multigravida & 7.641 & 1.555 & 1.488 & 0.288 & $5.399 *$ \\
Primigravida & 6.086 & & & & \\
\hline
\end{tabular}

*Significant at $\mathrm{df}=118, \mathrm{p}<0.05$, table value -1.9803

Data presented in table 5 depict that the t value is 5.399 at $\mathrm{df} 118$. The obtained value (5.399) is higher than the table value (1.9803) at 0.05 level of significance. It means the mean difference is true difference between primigravida and multigravida not by chance. Therefore, interference can be drawn that there is significant difference of need fulfilment between multigravida and primigravida women.

\section{Conclusion}

Maximum of women's needs and expectations are partially fulfilled whereas needs and expectations are also not fulfilled and total fulfilment score is very low. So there is an urgent need to promote more focus on different types of needs and expectations of women during intra-partum and immediate postpartum period. Health care provider has the responsibility to provide quality care to pregnant women, which can be ensured by fulfilling the all needs and expectations of the woman during intra partum and immediate postpartum period. Findings from the study can be utilized to improve the quality care of women during hospitalization. Awareness of nursing personnel is needed regarding needs and expectations of women during intra-partum and immediate postpartum period. Findings of this study can be utilized to sensitize the nursing personnel from very beginning of their preparation period.

\section{Recommendations}

- A similar study can be conducted on large sample in different setting.

- A qualitative study can be conducted on fulfillment of needs and expectations.

- A comparative study can be conducted between primigravida and multigravida o this area.

- A study on effect of interventional package regarding needs, expectations and fulfillment on satisfaction level of clients can be conducted.

\section{Acknowledgement}

The research is the product of many person's contribution, extensive help, intensive knowledge and skills, who supported and encouraged the investigator throughout the study. These contributors helped the investigator as friends, philosophers and guides. It is her privilege to offer heartfelt thanks to all of them for their timely help to complete the task on time.

The investigator sincerely thanks the lord for his abundant grace, mental strength, blessings and unconditional love bestowed on investigator throughout the study. 
The investigator expresses her deep sense of gratitude to her teacher and research guide Prof. Dr. Smritikana Mani, Principal of College of Nursing, Medical College \& Hospital, Kolkata for her invaluable guidance and opinions which inspired investigator in successful completion of the study. Without her motivation and help, it would have been difficult for the investigator to complete the research study.

The investigator would like to express her profound sense of gratitude and heartfelt thanks to Ms Manasi Jana, Reader of College of Nursing, Medical College \& Hospital, Kolkata for her valuable guidance, suggestions and opinions throughout the period of study.

The investigator extends sincere and heartiest thanks to all the faculty members of College of Nursing, Medical College \& Hospital, Kolkata for their valuable suggestions and encouragement which led to the successful completion of the study.

The investigator extends special gratitude to all experts for their valuable contribution in validating, translating and reviewing the data collection tools.

The investigator is very much obliged to the Medical Superintendent cum Vice Principal of Medical College \& Hospital, Kolkata for granting permission to conduct the study.

The investigator is indebted to the Head of the Department of Gynaecology and Obstetrics, Medical College \& Hospital, Kolkata for granting permission and facilitating the accomplishment of the study. The investigator is thankful to Nursing Superintendent, Sister-In-Charge and all staff of labour room and postnatal ward of Medical College \& Hospital, Kolkata.

The investigator gratefully mentions the efforts of Mr. Naresh Chandra Roy and Madhusudan Adhikary for language validation of data collection tool in English version and also in Bengali version.

The investigator's special thanks to the intra-partum and immediate postpartum women who have willingly participated and made the study possible.

An expression of gratitude goes to the librarians and other staff of the library of College of Nursing, Medical College \& Hospital, Kolkata.

Profound gratitude is expressed to Dr. Sandip Mondal, Associate Professor of Calcutta University, for his patient endeavour in editing dissertation.

The investigator acknowledges the perseverance, understanding, and extension of encouragement and constant moral support of her family members during the entire period of the study. Word of acknowledgement would be incomplete if investigator does not express her sincere thanks to all friends and classmates.

The investigator extends her gratitude to all other members who directly and indirectly contributed their co-operation for the successful completion of research project. 


\section{Appendix A}

\section{A1: Letter seeking permission from Principal of C O N, Medical College \& Hospital}

\section{To}

The Principal,

College of Nursing

Medical College and Hospital

Kolkata -73

Subject: Requesting for permission for conducting a research study for fulfillment of M.Sc. Nursing course at College of Nursing, Medical College and Hospital

Respected Madam,

I beg to state that I, Najnina Khatun, M. Sc. Nursing student of College of Nursing, Medical College and Hospital, Kolkata. As per the requirement by The West Bengal University of Health Sciences, I have to complete a research dissertation for completion of M.Sc. Nursing course.

The topic selected for research study is "Does the health care provider fulfill the needs and expectations of women during intra-partum and immediate post-partum period in a selected Govt. Hospital of West Bengal"?

I will bear all the expenses of the research project on my own and will have informed consent and permission of the participants and concerned authorities before starting the study. Privacy, safety and confidentiality of all the study participants will be maintained strictly.

I shall be highly obliged if you kindly grant permission to conduct the proposed study.

Thanking you, Yours sincerely

Najnina Khatun

M.Sc. Nursing student

College of Nursing, Medical College \&Hospital,

Kolkata

Date: 


\section{A2: Letter seeking permission from Institutional Ethical Committee}

To,

The Chairperson

Institutional Ethical Committee

Medical College and Hospital

Kolkata-73

(Through proper channel)

Subject: Application for ethical clearance for prposed study

Sir/Madam,

I beg to state that I, Najnina Khatun, M. Sc. Nursing student of College of Nursing, Medical College and Hospital, Kolkata. As per the requirement by The West Bengal University of Health Sciences, I have to complete a research dissertation for completion of M.Sc. Nursing course.

The topic selected for research study is "Does the health care provider fulfill the needs and expectations of women during intra-partum and immediate post-partum period in a selected Govt. Hospital of West Bengal'? under the guidance of Prof. (Dr) Smritikana Mani, Principal of College of Nursing, Medical College and Hospital, Kolkata.

I will bear all the expenses of the research project on my own and will have informed consent and permission of the participants and concerned authorities before starting the study. Privacy, safety and confidentiality of all the study participants will be maintained strictly.

I shall be highly obliged if you kindly grant permission to conduct the proposed study.

Thanking you, Yours sincerely

Najnina Khatun

M.Sc. Nursing student

College of Nursing, Medical College \&Hospital,

Kolkata

Date: 


\title{
A3: Letter seeking permission from the Director of Health Services
}

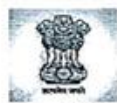 \\ Government of West Bengal \\ Office of the Principal \\ Govt. College of Nursing \\ Medical College \& Hospital, Kolkata-700073, W.B \\ Phone No. 033-22551600 / 22123870 FAX-033-22123806 E-mail:- medcon15kolkata@gmail.com \\ Memo No-HCN/CON/MCH/ $943 \quad$ Date:- 25/9//8 \\ To \\ The Director of Health Service \\ Swasthya Bhavan, GN-29, Sector -V, Salt Lake City, \\ West Bengal, Kolkata-700091
}

Subject: Seeking permission for conducting the pilot study from 4.10 .18 to 11.10 .18 and final research study from 15.10.18 to 17.11 .18

Respected Sir/Madam,

I would like to introduce Ms. Najnina Khatun, final year M.Sc. Nursing student of this college to you. She has to conduct a research project and to submit to The West Bengal University of Health Sciences as a requirement of her course.

The topic selected for her research study is "Does the health care provider fulfill the needs and expectations of women during intra-partum and immediate post-partum period in a selected Govt. Hospital of West Bengal"?

The student is in need of your esteemed help and co-operation as she is interested in conducting pilot study from 4.10.18 to 11.10 .18 and final study from 15.10 .18 to 17.11 .18 at Medical College and Hospital, Kolkata.

Therefore, I am requesting you to kindly give the permission and kindly extend necessary facilities to her work on the proposed study. Further information in this regard if any will be furnished by the student personally.

Thanking you.

Date:
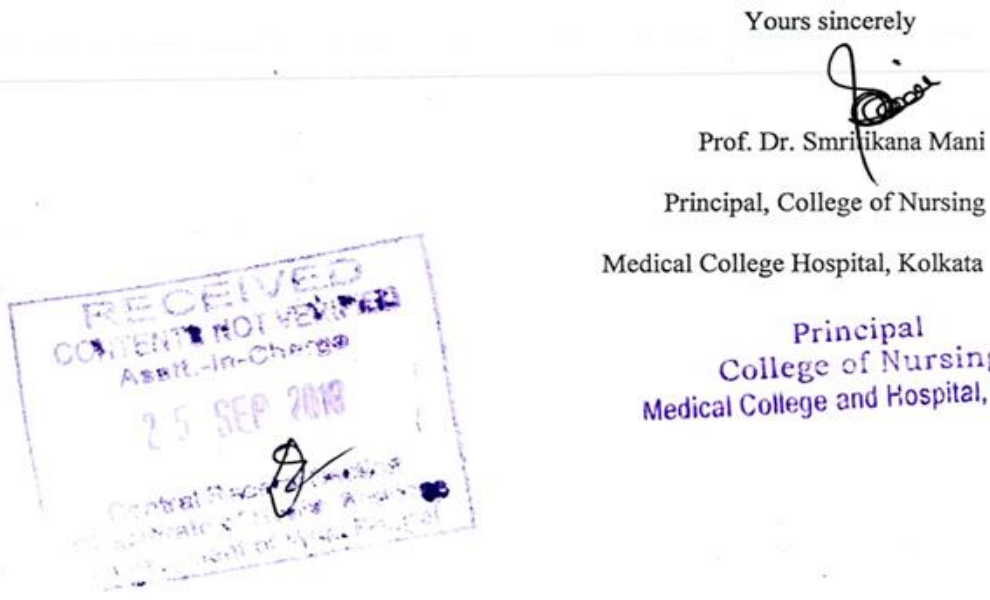

Medical College Hospital, Kolkata

Principal

College of Nursing

Medical College and Hospital, Kolkata 


\section{A4: Letter seeking permission from the Joint Director of Health Services (Nursing)}

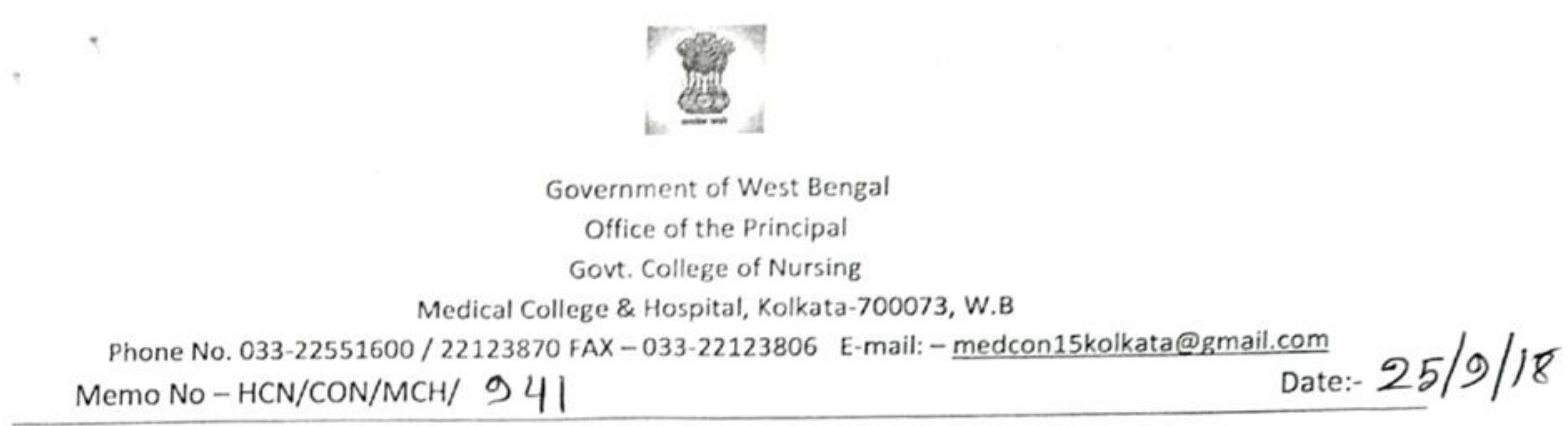

To

The Joint Director of Health Services (Nursing)

Directorate of Health Service West Bengal

Swasthya Bhavan, GN-29, Sector -V, Salt Lake City,

West Bengal, Kolkata-700091

Subject: Seeking permission for conducting the pilot study from 4.10 .18 to 11.10 .18 and final research study from 15.10 .18 to 17.11 .18

Respected Sir/Madam,

I would like to introduce Ms. Najnina Khatun, final year M.Sc. Nursing student of this college to you. She has to conduct a research project and to submit to The West Bengal University of Health Sciences as a requirement of her course.

The topic selected for her research study is "Does the health care provider fulfill the needs and expectations of women during intra-partum and immediate post-partum period in a selected Govt. Hospital of West Bengal"?

The student is in need of your esteemed help and co-operation as she is interested in conducting pilot study from 4.10.18 to 11.10 .18 and final study from 15.10 .18 to 17.11 .18 at Medical College and Hospital, Kolkata.

Therefore, I am requesting you to kindly give the permission and kindly extend necessary facilities to her work on the proposed study. Further information in this regard if any will be furnished by the student personally.

Thanking you.

Date:

Place:

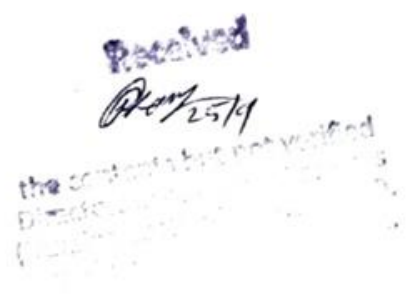

Yours sincerely

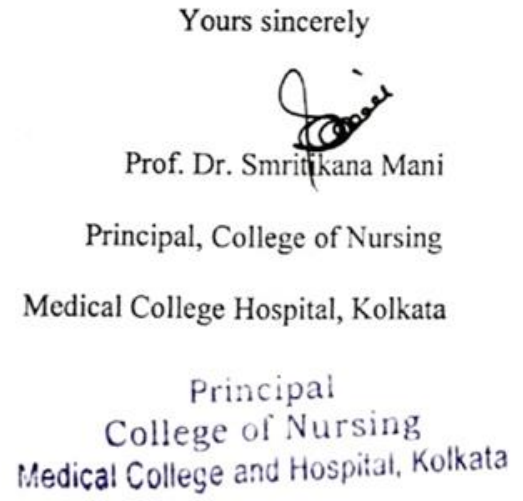

Medical College and Hospital, Kolkata 


\title{
A5: Letter seeking permission from MSVP of Medical College and Hospital
}

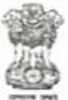 \\ Government of West Bengal \\ Office of the Principal \\ Govt. College of Nursing \\ Medical College \& Hospital, Kolkata-700073, W.B \\ Phone No. 033-22551600/22123870 FAX - 033-22123806 \\ E-mail:-medcon15koikata@gmail.com

$\mathrm{Memo} \mathrm{No}-\mathrm{HCN} / \mathrm{CON} / \mathrm{MCH} / 119 \mathrm{Date}-14,11,18$ \\ To \\ The Medical Superintendent cum Vice Principal \\ Medical College and Hospital \\ Kolkata
}

Subject: Seeking permission for conducting the Pilot study from 4.10.18 to 11.10.18 by M.Sc. Nursing Final Year student of College of Nursing, Medical College \& Hospital, Kolkata-73.

Respected Sir/Madam,

I have the honour, to bring it to your kind information that according to the Government order vide Memo no. HNG/10P-3-2016/Pt-IV 893 dated 02/11/2018, Miss Najnina Khatun, M.Sc. Nursing, Final year student of College of Nursing, Medical College \& Hospital, Kolkata, has been selected to undergo the study mentioned below for the Research project to be submitted to The West Bengal University of Health Sciences for partial fulfillment of university requirements of Master of Science degree in Nursing.

Problem statement for Dissertation: "Does the health care provider fulfill the needs and expectations of women during intra-partum and post-partum period in a selected govt. hospital of West Bengal"?

In this connection, she is in need of your necessary permission on all sorts of cooperation in conduction of her pilot study at the following settings of your institution (if needed the data collection period may be extended).

Pilot Study: Medical College and Hospital, Kolkata.

Therefore, I would like to solicit your benign approval with all respective concern as to facilitate her to conduct the study at your early convenience please.

Thanking you

Yours sincerely

Date: $14 \cdot 11 \cdot 2018$

Place: Kolkata.

Prof. Dr Smritikana Mani

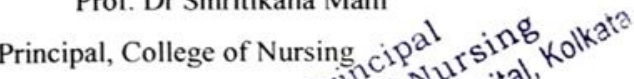

Memo no- $\mathrm{HCN} / \mathrm{CON} / \mathrm{MCH} /$

Copy forwarded to:

4. The HOD, Gynecology \& Obstetrics Department, MCH, Kol-73.

5. The Nursing Superintendent, $\mathrm{MCH}, \mathrm{Kol}-73$.

6. The Sister in charge, Labour Room, MCH, Kol-73.
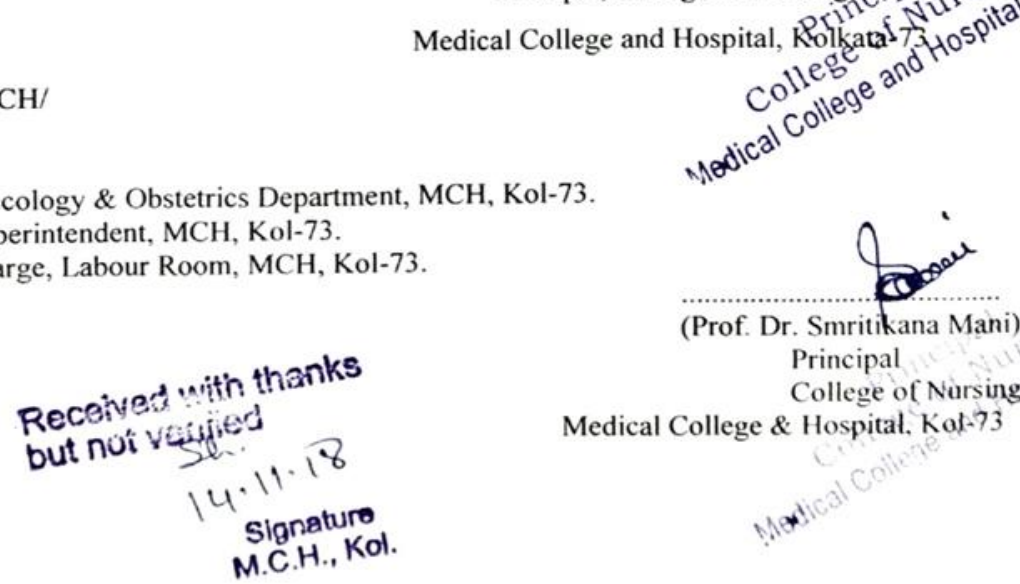

(Prof. Dr. Smritikana Mani) Principal College of Nursing Medical College \& Hospital, Kol-73 


\title{
A6: Letter seeking permission from MSVP of Medical College and Hospital
}

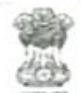 \\ Government of West Bengal \\ Office of the Principal \\ Govt. College of Nursing \\ Medical College \& Hospital. Kolkata-700073, W.B \\ Phone No. 033-22551600/2?123870 FAX - 033-22123806 \\ E-mail:-medconI5kolkata@gmail.com

$\mathrm{Memo} \mathrm{No-HCN} / \mathrm{CON} / \mathrm{MCH} / 1120$ \\ To \\ The Medical Superintendent cum Vice Principal \\ Medical College and Hospital \\ Kolkata
}

Subject: Seeking permission for conducting the Final study 15.10.18 to 17.11.18 by M.Sc. Nursing Final Year student of College of Nursing, Medical College \& Hospital, Kolkata-73.

Respected Sir/Madam,

I have the honour, to bring it to your kind information that according to the Government order vide Memo no. HNG/10P-3-2016/Pt-IV 893 dated 02/11/2018, Miss Najnina Khatun, M.Sc. Nursing, Final year student of College of Nursing, Medical College \& Hospital, Kolkata, has been selected to undergo the study mentioned below for the Research project to be submitted to The West Bengal University of Health Sciences for partial fulfillment of university requirements of Master of Science degree in Nursing.

Problem statement for Dissertation: "Does the health care provider fulfill the needs and expectations of women during intra-partum and post-partum period in a selected govt. hospital of West Bengal"?

In this connection, she is in need of your necessary permission on all sorts of cooperation in conduction of her final study at the following settings of your institution (if needed the data collection period may be extended).

Final Study: Medical College and Hospital, Kolkata.

Therefore, I would like to solicit your benign approval with all respective concern as to facilitate her to conduct the study at your early convenience please.

Thanking you

Date: $14.11 \cdot 18$

Place: KolKala.

Prof. Dr Smpritikanga Maps

Yours sincerely

Memo no- $\mathrm{HCN} / \mathrm{CON} / \mathrm{MCH} /$

Copy forwarded to:

1. The HOD, Gynecology \& Obstetrics Department, $\mathrm{MCH}, \mathrm{Kol}-73$.

2. The Nursing Superintendent, $\mathrm{MCH}, \mathrm{Kol}-73$.

3. The Sister in charge, Labour Room, MCH, Kol-73.
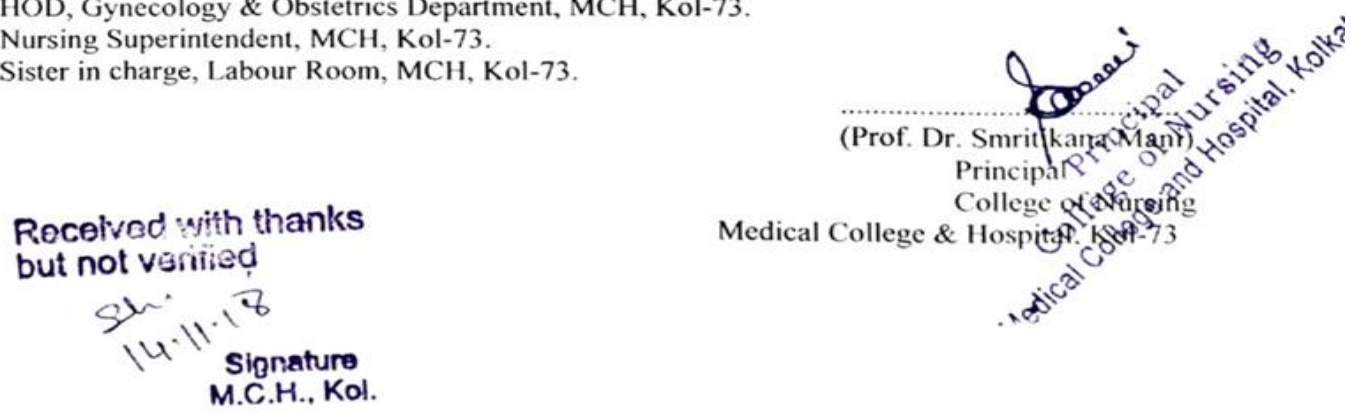

Medical College \& Hospity? I I OP-73 


\section{Appendix B}

\section{B1: Letter granting permission from Principal of C O N, Medical College \& Hospital}

To

The Principal

College of Nursing

Medical College \& Hospital

Kolkata-700073

\section{(Through proper channel)}

Sub: Requesting permission to conduct the research study.

Respected Madam.

With due respect \& humble submission I. Najnina Khatun. M.Sc. Nursing student of College of Nursing, Medical College \& Hospital, Kolkata beg to state that I have to conduct a research project for the partial fulfilment of the University's requirement for the award of M.Sc. degree in nursing. The study will be conducted at Medical College and Hospital. Kolkata.

The statement of the problem is----.

"Does the health care provider fulfill the needs and expectations of women during intrapartum and immediate postpartum period in a selected Govt. hospital of West Bengal?"

In this matter I would like to request you to grant permission to conduct the study in the pre-mentioned location.

Thanking you.

Dated:

Yours faithfully,

$$
\begin{gathered}
\text { Nänina Khortun. } \\
\text { Majnina Khatun } \\
\text { M.Sc. Nursing Student } \\
\text { College of Nursing } \\
\text { Medical College and Hospital } \\
\text { Kolkata }
\end{gathered}
$$

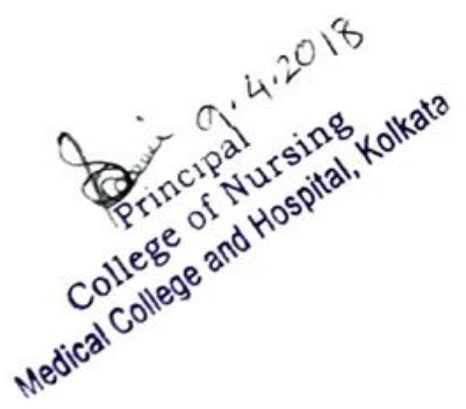




\section{B2: Letter granting permission from Institutional Ethical Committee}

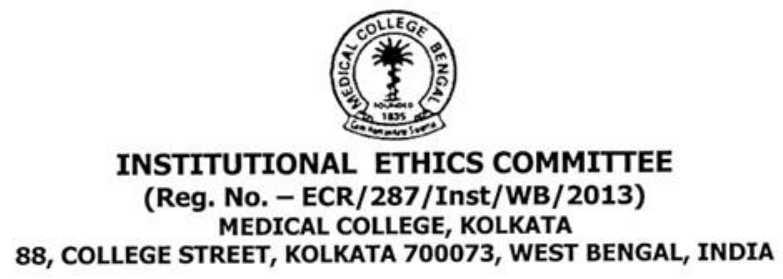

Chairperson

Prof. S. K. Maitra

Member Secretary

Prof. A.K.Bhadra

Members

Prof. Aniruddha Sengupta Prof. Debabrata Bandyopadhyay Prof. Tapan Mukhopadhyay Prof. Manideepa Sengupta Prof. Suhrita Pal

Dr. Rudrajit Paul

Dr. NilayKanti Das Mr. Hironlal Majumdar Ms. Sebanti Bhattacharya

Ms. Suhrita Saha

Ms. Rehana Khatun

Mr. Ashok Kar

\section{Ref No MC/KOL/IEC/ NON-SPON/71/05-2018}

To,

Ms. Najnina Khatun,

M.Sc Nursing $1^{\text {st }}$ year student,

College of Nursing,

Medical College \& Hospital, Kolkata

Study Title: Problem Statement: Bengal?

Dear Student,
Dated: 12.05 .2018

Sub.: IEC-MCH Decision of the review of study ref No. nil , dated nil .

Does the health care provider fulfill the needs and expectation of women during intrapartum and immediate postpartum period in a selected Govt. Hospital of West

In its meeting held on $12^{\text {th }}$ May, 2018, the members of the IEC, Medical College, Kolkata, the above related documents were examined, reviewed and discussed your proposal to conduct the above mentioned study.

The following members of the committee were present (ticked against their names):

Chairperson: Prof. Susanta Kr. Maitra, Pharmacologist

Member Secretary: Prof. Ashok Kumar Bhadra, Principal, MCH

$$
\begin{aligned}
& \text { Menbers } \\
& \text { Dof. Aniruddha Sengupta (Clinician) } \\
& \text { Prof-Debabrata Bandyopadhyay (Clinician) } \\
& \text { Dfof Tapan Mukhopadhyay (Basic Scientist) } \\
& \text { Prof Manideepa Sengupta (Basic Scientist) } \\
& \text { Prof. Suhrita Pal (Pharmacologist) } \\
& \text { Dr. Rudrajit Paul (Clinician) } \\
& \text { Dr. HilayKanti Das (Clinician) } \\
& \text { Wh. Hitonlal Majumdar (Legal Expert) } \\
& \text { Us. Sebanti Bhattacharya (Philosopher) } \\
& \text { Ms. Suhrita Saha (Sociologist) } \\
& \text { Ms. Rehana Khatun (Medically Lay person) } \\
& \text { M. Ashok Kar (Medically Lay person) }
\end{aligned}
$$

Page 1 of 2 
B2

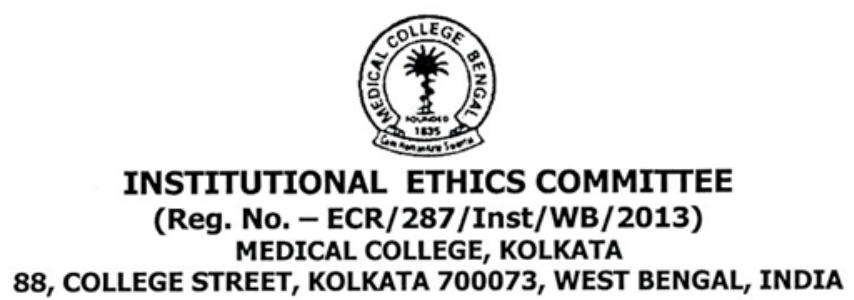

Study Title: : Problem Study: Does the health care provider fulfill the needs and expectation of women during intra-partum and immediate postpartum period in a selected Govt. Hospital of West Bengal?

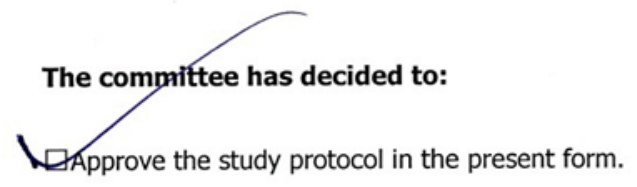

$\square$ Conditionally approve the study protocol subject to

$\square$ Reject the proposal for the following reasons

\section{You are required to:}

i) Inform the committee about the progress of the study and compliance of ethical guidelines.

ii) Notify the committee regarding any serious adverse events occurring in the course of the study.

iii) Inform and seek approval of the committee about any changes in the protocol prior to their implementation.

iv) Submit the final report to the committee in every case.

This Ethics committee is working in accordance with the ICH-GCP, Schedule $Y$ and ICMR guidelines and other applicable regulations.

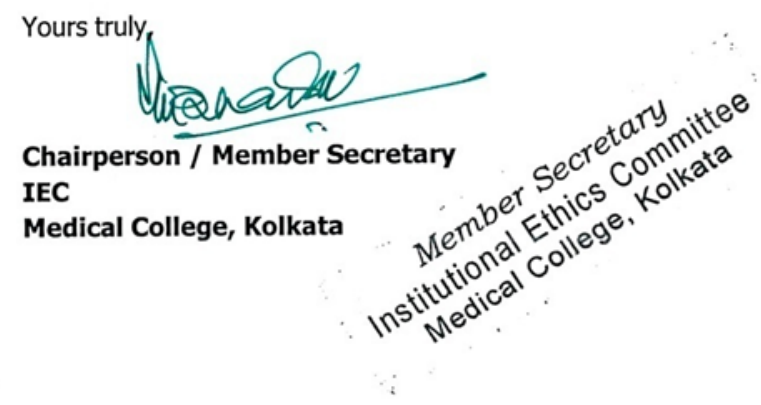

Page 2 of 2 
Appendix C

\section{C1: Letter seeking Expert's opinion for content validity}

To

Subject: Requesting letter for seeking expert's opinion \& suggestion for content validation of data collection tool.

Respected Sir/Madam

I Najnina Khatun, M.Sc. Nursing student, in order to meet the course requirement, going to conduct a dissertation work.

Topic: "Does the health care provider fulfill the needs and expectations of women during intrapartum and immediate post-partum period in a selected Govt. Hospital of West Bengal"?

\section{Objectives}

1) To assess the needs of the women during intra-partum and immediate postpartum period.

2) To assess the expectations of the women during intra-partum and immediate postpartum period.

3) To assess the care provided by the health care provider to fulfill the needs and expectations of women during intra-partum and immediate postpartum period

\section{For above purpose I have prepared}

- $\quad$ A structured questionnaire for demographic variables.

- $\quad$ Semi structured questionnaire to identify needs and expectations.

- 3 point rating scale to assess fulfillment of needs and expectations.

I am requesting you to kindly go through the content of the tool and give your expert opinion and suggestion about the appropriateness of the item which needs to be modified and deleted by using evaluation checklist. I would like to go take your permission for keeping your name in the expert list of my dissertation.

This is also my request that, kindly sign the certificate of validation that is enclosed with tool. I will remain grateful if you kindly provide me your expert judgment by checking my tool.

Thanking you.

Date:

Yours sincerely

Najnina Khatun

M.Sc. Nursing student

College of Nursing

Medical College \& Hospital

Kolkata 


\section{C2: Certificate for tool validation}

\section{To Whom It May Concern}

This is to certify that the tool which was developed by Ms. Najnina Khatun, student of M.Sc. Nursing, College of Nursing, Medical College \& Hospital, Kolkata-73 on research topic "Does the health care provider fulfill the needs and expectations of women during intra-partum and immediate post-partum period in a selected Govt. Hospital of West Bengal ?" has been validated by me and the comments are noted.

\section{Signature:}

Name:

Designation:

Date:

Seal: 
[Khatun et. al., Vol.7 (Iss.10): October 2019]

ISSN- 2350-0530(O), ISBN- 2394-3629(P)

Index Copernicus Value (ICV 2018): 86.20

POI: $10.5281 /$ zenodo.3522165

D1: Certificate for editing the research study

Editing certificate for research study

To whom it may concern

This is to certify that Ms. Najnina Khatun, final year M.Sc. Nursing student (2017-2019), College of Nursing, Medical College \& Hospital, Kolkata-73 has made the necessary editorial changes successfully. Her dissertation paper is titled "Does the health care provider fulfil the needs and expectations of women during intra-partum and immediate post-partum period in a selected Govt. Hospital of West Bengal ?”

I wish her success in life.

Date: $21 \cdot 05 \cdot 19$

Place: Kook otto

[130]

Http://www.granthaalayah.com @ International Journal of Research - GRANTHAALAYAH

BResigrat NANDAL

Associate Professor Dept of English University of Calico. 


\section{Appendix E}

\section{E1: Informed Consent Form in English}

I have been properly explained by the researcher the purpose and method of this research (Does the health care provider fulfill the needs and expectations of women during intra-partum and immediate postpartum period in a selected Govt. hospital of West Bengal?). My participation in this study is purely voluntary and I can withdraw from the study whenever I wish. I have also understood that the researcher can take any decision regarding my participation in the study. I will not be given any incentive for participating in this study. After agreeing to participate in this study I give my full consent for participation and shall fully cooperate with the researcher for achievement of the objectives provided confidentiality is maintained.

$\begin{array}{lc}\text { NAME OF THE PARTICIPANT } & : \\ \text { SIGNATURE/LTI } & : \\ \text { DATE } & : \\ \text { NAME OF THE WITNESS } & : \\ \text { SIGNATURE } & : \\ \text { DATE } & : \\ \text { NAME OF RESEARCHER } & : \\ \text { SIGNATURE } & : \\ \text { PHONE NO } & : \\ \text { DATE } & :\end{array}$




\section{Appendix F}

\section{Data collection tool}

\section{F1: Semi structure Interview Schedule Part I}

Purpose- To collect demographic data from intra partum women.

Instruction - The investigator will ask questions and put tick ( ) mark against the answer given by the women.

Code no:

1) Age:................

i. $\quad 18$ years to 28 years ( )

ii. 29 years to 39 years ( )

iii. >39 years ( )

2) Religion $: . . . \ldots \ldots \ldots \ldots \ldots$

i. Hindu ( )

ii. Muslim ()

iii. Christian or others ( )

3) Type of family

i. Nuclear family ( )

ii. Joint family ( )

iii. Extended family ( )

4) Educational qualification

i. Illiterate ( )

ii. Primary ( )

iii. Madhyamik

iv. Higher secondary and above ( )

5) Occupation :

i. Homemaker ( )

ii. Business

iii. Service

6) Monthly income:

i. < Rs 2000 per month ( )

ii. Rs 2001 to $5000 /$ month ( )

iii. Rs 5001 to 10000 per month ( )

iv. > Rs 10000 per month ( )

7) Gravida :

i. Primi-gravida ( )

ii. Multi-gravida ( ) 


\section{F 2 Semi structured interview schedule}

Purpose - To assess the needs of the women during intra-partum and immediate postpartum period.

Instruction - The investigator will ask the questions and write the answers given by the women in intra-partum \& immediate post-partum period.

\section{Code no:}

\section{Part II (A) Intra-partum period}

\section{Informational needs}

Q.1. What information do you need regarding the ward environment (like location of basin, toilet and bathroom, Doctors and nurses station etc)?

Q.2 What information do you need regarding your labour and delivery process? (Foetal condition, Time of delivery, Plan of delivery, Who will stand besides you, Who will conduct delivery, Whom to call in emergency, What to do \& not to do).

\section{Physiological needs}

Q.3. What do you want to get services regarding your physiological needs? (information about whom to call in nausea, vomiting or headache occur, information whom to call if foetal movement is less, to check blood pressure, pulse, to check foetal heart rate, Information about type of diet to be taken during, before, after delivery, help to take light diet, help to take drinking water).

\section{Personal and Psychological needs}

Q.4. What services do you want to get to maintain your personal hygiene? (Help to clean the body or to take bath, help to change the clothing)

Q.5. What do you want to maintain your physical comfort in this ward? (comfortable environment in terms of light, temperature and cleanliness, Clean bed linen).

Q.6. What kind of behaviour do you want to get from health care provider? (Behave kindly with you, verbal encouragement, Response in calling).

\section{Social needs}

Q.7.What are your needs to maintain communication regarding delivery from health care provider? (Allowing support person like one family member to stay with you, Communication of the health care provider with you, Communication of the health care provider with family member).

\section{Esteems needs}

Q.8. What are your needs regarding respectful maternity care like maintain privacy during check up or delivery like use of curtain, screen, no physical harm, consent before doing any procedure, equal treatment indiscriminating caste, creed, rich or poor, respect like calling by "name" or by "you", freedom in care like involvement in decision making, allowing comfortable position for delivery, to get timely care. 


\section{Security needs}

Q.9.What are your needs regarding security? (Explanation about every procedure, Removing fear of childbirth process, Removing -fear of losing baby).

\section{Treatment needs}

Q.10. What do you want to get treatment or medical services? (Pain relieving measures to relieve pain, Prevention of unnecessary intervention like frequently use of urinary catheter and vaginal examination.)

\section{Part II (B) \\ Immediate postpartum period}

\section{Informational needs}

\section{Regarding newborn care}

1. What information do you need regarding breast feeding (when to initiate breast feeding, either colostrums is given or not, breastfeeding technique)?

2. What information do you need to know from health care provider to maintain warmth of newborn (type of baby's clothing, time of bathing)?

3. What information do you need to know from health care provider regarding baby's immunizations like when or where to give immunization?

4. What information do you need to know from health care provider to prevent infection?

5. What information do you need to know from health care provider to know the signs of baby is getting enough milk?

6. What information do you need to know from health care provider about the danger signs of baby?

\section{Regarding self care}

7. What information do you want to know regarding postnatal diet?

8. What information do you want to know to take perineal care like dressing, pad changing ?

9. What information do you want to know about the danger signs of postnatal mother?

\section{Assistance needs}

10. What services do you want from health care provider to take care of self (assistance to change clothing, sanitary napkin, cleaning extremities, in ambulation) and newborn care (supporting to hold baby during breastfeeding)?

\section{Pain relieving needs}

11. What do you need to relieve pain at perineal area?

\section{Nutritional needs}

12. What do you want to get services regarding nutrition like providing food and water?

\section{Other need}

13. What other information or services do you want from health care provider during intrapartum or immediate postpartum period? 


\section{F 3: 3 point Rating Scale}

Purpose: To assess the care provided by the health care provider to fulfil the expectations of women during intra-partum and immediate post-partum period.

Instruction: During intra-partum and post partum period women have some expectations from health care provider to fulfil their needs. I would like to assess the care to fulfil the expectations of women during intra-partum and immediate post partum period. I will ask some statement and you will give answer according to your expectations are fulfilled by "totally fulfilled" "partially fulfilled" or "not fulfilled".

\section{Code no:}

Intra-partum period (Part III A)

\begin{tabular}{|c|c|c|c|c|c|c|}
\hline $\begin{array}{l}\text { Sl } \\
\text { no }\end{array}$ & $\begin{array}{c}\text { Area \& Sub } \\
\text { area }\end{array}$ & \multicolumn{2}{|r|}{$\begin{array}{l}\text { Expectations (fulfilment of needs) of } \\
\text { women during intra-partum period }\end{array}$} & $\begin{array}{l}\text { Totally } \\
\text { fulfilled }\end{array}$ & $\begin{array}{l}\text { Partially } \\
\text { fulfilled }\end{array}$ & $\begin{array}{c}\text { Not } \\
\text { fulfilled }\end{array}$ \\
\hline 1 & $\begin{array}{l}\text { Informational } \\
\text { need } \\
\text { a. Hospital } \\
\text { Environment }\end{array}$ & & $\begin{array}{l}\text { Health care provider gave full } \\
\text { information about location of basin, } \\
\text { toilet and bathroom after admission. } \\
\text { Health care provider shown you the } \\
\text { nurses and Doctors station. }\end{array}$ & & & \\
\hline & $\begin{array}{l}\text { b. Labour \& } \\
\text { Delivery }\end{array}$ & & $\begin{array}{l}\text { Health care provider gave } \\
\text { information about who will stand } \\
\text { besides you during delivery. } \\
\text { Who will conduct the delivery either } \\
\text { doctor or nursing staff was informed } \\
\text { by health care provider. } \\
\text { Information about foetal condition } \\
\text { was given by health care provider. } \\
\text { Health care provider informed you } \\
\text { about the time of labour. } \\
\text { Health care provider informed you } \\
\text { about the plan of delivery like } \\
\text { normal or caesarean section. } \\
\text { Health care provider informed you } \\
\text { whom to call if any problem occur. } \\
\text { Health care provider gave } \\
\text { information about do's and don'ts } \\
\text { during labour like ambulation till } \\
\text { membrane is intact, don't give } \\
\text { bearing down pain in first stage, } \\
\text { don't take heavy food before } \\
\text { delivery }\end{array}$ & & & \\
\hline
\end{tabular}




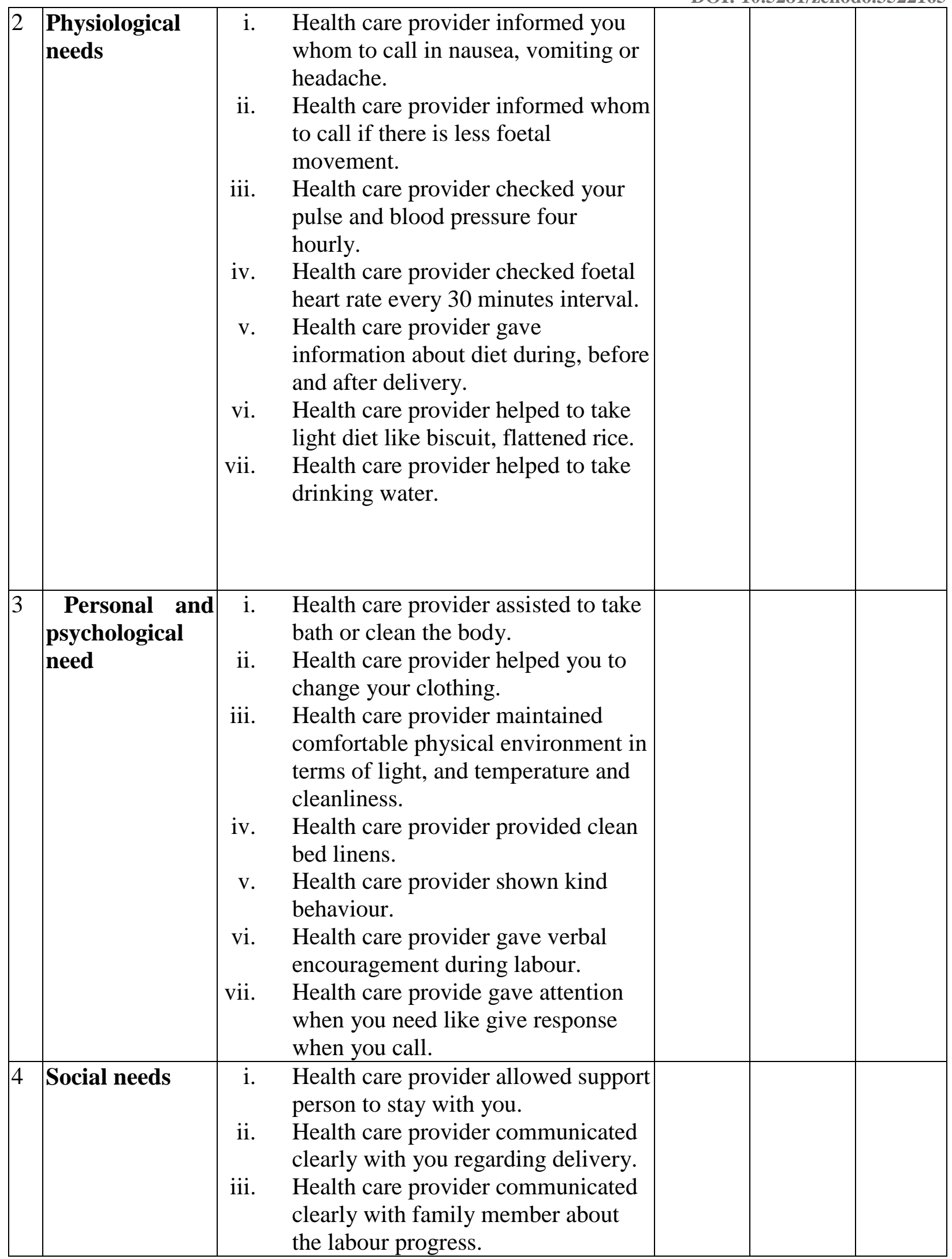




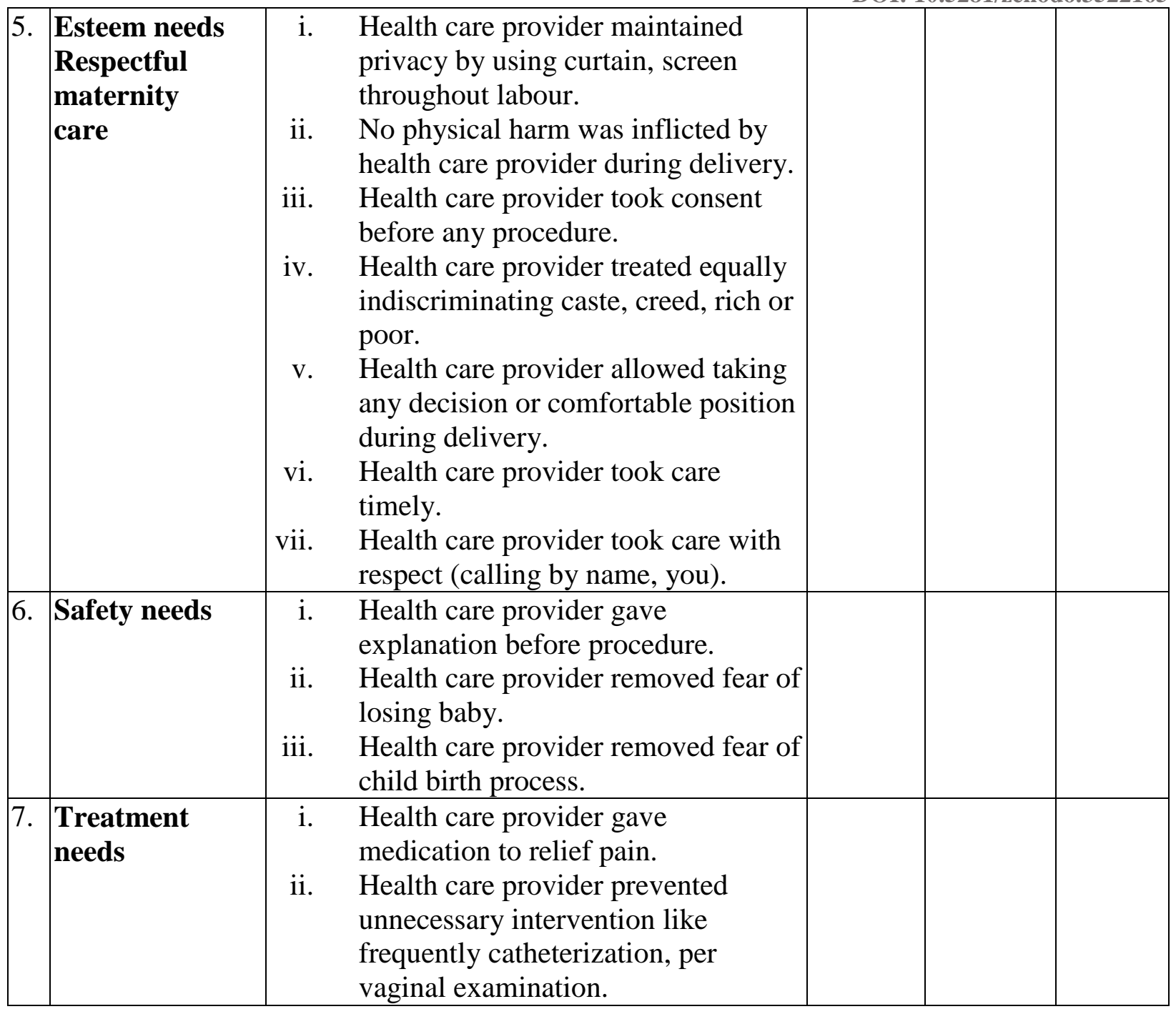

Immediate post-partum period (Part III B)

\begin{tabular}{|c|c|c|c|c|c|}
\hline $\begin{array}{l}\text { Sl } \\
\text { no }\end{array}$ & $\begin{array}{l}\text { Area \& sub } \\
\text { area }\end{array}$ & $\begin{array}{l}\text { Expectation (fulfilment of needs) } \\
\text { of women during immediate post- } \\
\text { partum period }\end{array}$ & $\begin{array}{l}\text { Totally } \\
\text { fulfilled }\end{array}$ & $\begin{array}{l}\text { Partially } \\
\text { fulfilled }\end{array}$ & $\begin{array}{c}\text { Not } \\
\text { fulfilled }\end{array}$ \\
\hline 1 & $\begin{array}{l}\text { Informational } \\
\text { needs } \\
\text { a. Newborn } \\
\text { care }\end{array}$ & 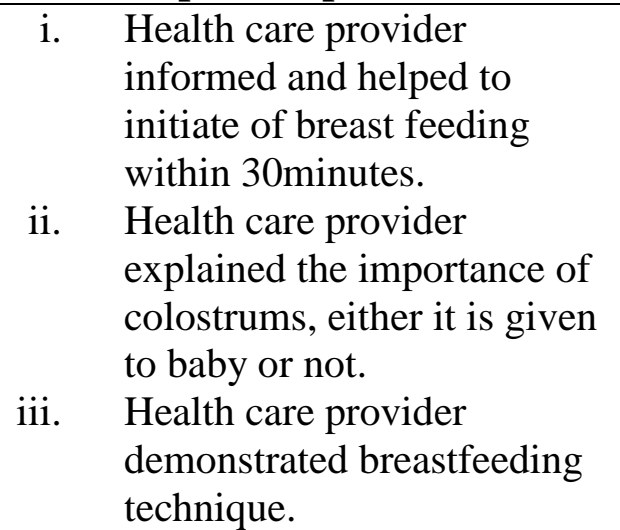 & & & \\
\hline
\end{tabular}




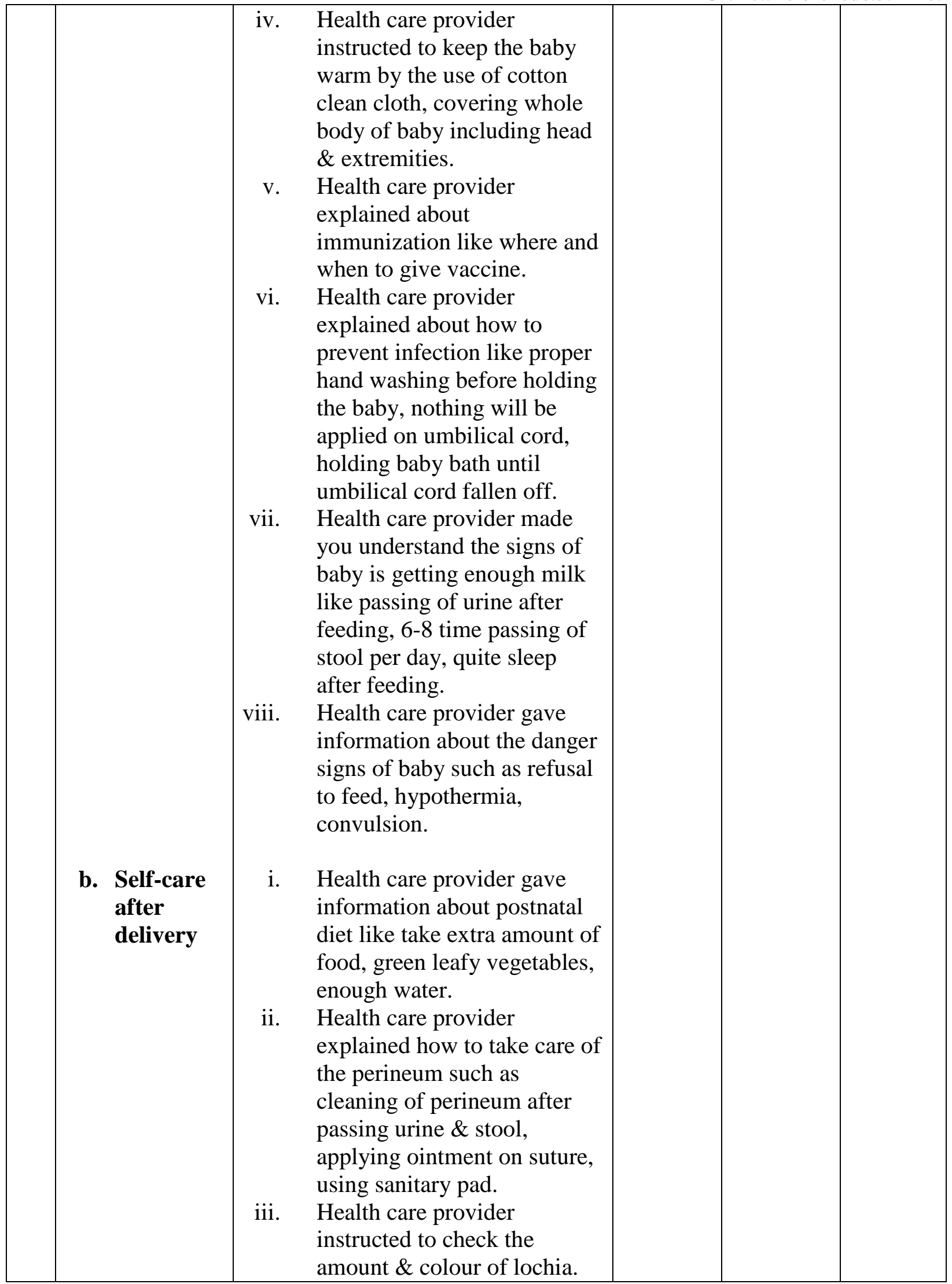




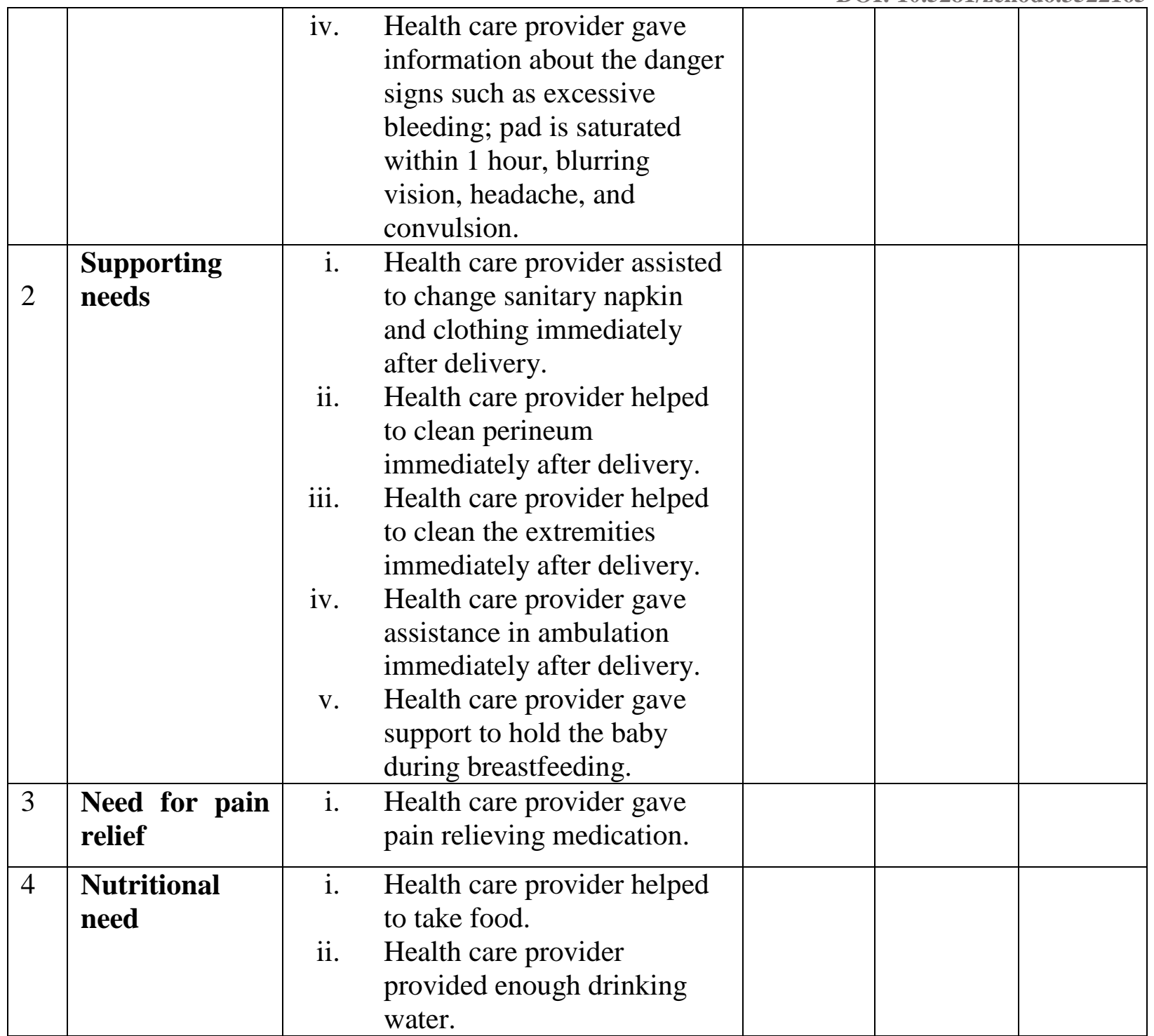

F 4: 3 point Rating Scale (Fulfilment of needs and expectation)

\begin{tabular}{|l|l|l|}
\hline SI no. & $\begin{array}{c}\text { Expectations } \\
\text { (fulfilment of needs) }\end{array}$ & Code \\
\hline 1 & Totally fulfilled & $\mathrm{T}$ \\
\hline 2 & Partially fulfilled & $\mathrm{P}$ \\
\hline 3 & Not fulfilled & $\mathrm{N}$ \\
\hline
\end{tabular}


G 1: Part II A (Semi Structured Interview Schedule)

\begin{tabular}{|c|c|c|c|c|c|c|c|c|c|c|c|c|c|c|c|c|c|c|c|c|c|c|c|}
\hline & & & Info & rma & tior & lal ne & eds & & & & & ysio & $\log i$ & cal ne & eds & & & rsonal & $\begin{array}{l}181 \\
\text { ne }\end{array}$ & $\begin{array}{l}\text { Psyc } \\
\text { eds }\end{array}$ & chol & & \\
\hline $\begin{array}{l}\text { ż } \\
\text { o } \\
0\end{array}$ & 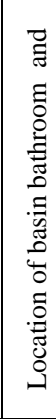 & 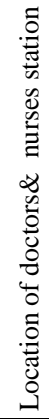 & 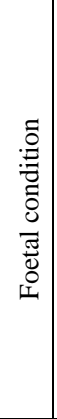 & 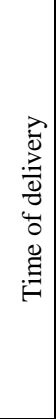 & 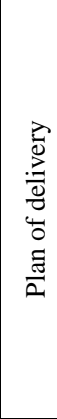 & 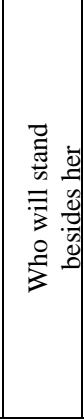 & 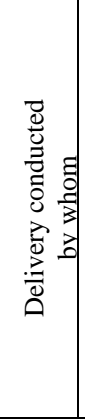 & 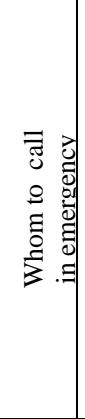 & 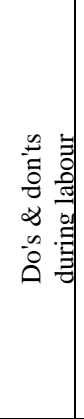 & 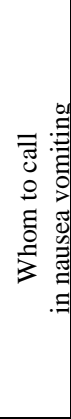 & 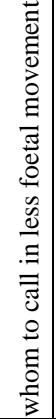 & 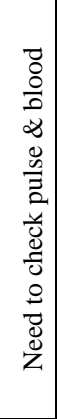 & 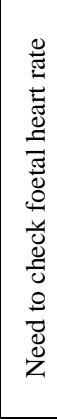 & 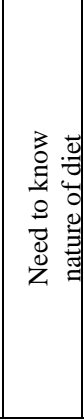 & 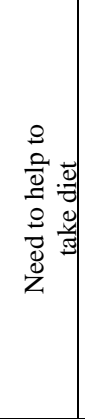 & 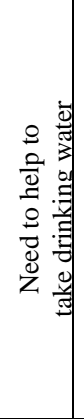 & 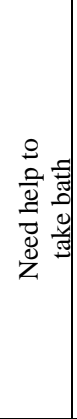 & 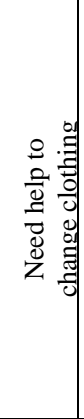 & 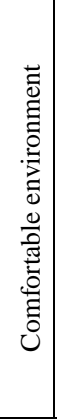 & 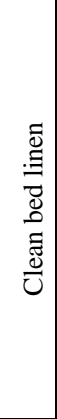 & 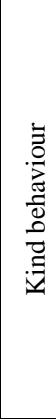 & 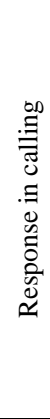 & 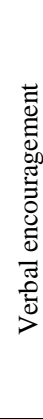 \\
\hline 1 & 1 & 0 & 1 & 1 & 1 & 1 & 1 & 0 & 1 & 1 & 1 & 1 & 1 & 1 & 1 & 1 & 0 & 0 & 1 & 1 & 1 & 1 & 1 \\
\hline 2 & 1 & 1 & 1 & 1 & 1 & 1 & 1 & 1 & 1 & 1 & 1 & 1 & 1 & 1 & 1 & 1 & 0 & 1 & 1 & 1 & 1 & 1 & 1 \\
\hline 3 & 0 & 0 & 1 & 1 & 1 & 1 & 1 & 1 & 1 & 1 & 1 & 1 & 1 & 1 & 1 & 1 & 0 & 1 & 1 & 1 & 1 & 1 & 1 \\
\hline 4 & 1 & 0 & 1 & 0 & 1 & 1 & 1 & 1 & 1 & 1 & 1 & 1 & 1 & 1 & 1 & 1 & 1 & 1 & 1 & 1 & 1 & 1 & 1 \\
\hline 5 & 1 & 1 & 1 & 1 & 1 & 1 & 1 & 1 & 1 & 1 & 1 & 1 & 1 & 1 & 1 & 1 & 0 & 1 & 1 & 1 & 1 & 1 & 1 \\
\hline 6 & 1 & 0 & 1 & 1 & 1 & 1 & 1 & 0 & 1 & 1 & 1 & 1 & 1 & 1 & 1 & 1 & 0 & 0 & 1 & 1 & 1 & 1 & 1 \\
\hline 7 & 1 & 1 & 1 & 1 & 1 & 1 & 1 & 1 & 1 & 1 & 1 & 1 & 1 & 1 & 1 & 1 & 1 & 1 & 1 & 1 & 1 & 1 & 1 \\
\hline 8 & 1 & 0 & 1 & 1 & 1 & 1 & 1 & 0 & 1 & 1 & 1 & 1 & 1 & 1 & 0 & 1 & 0 & 0 & 1 & 1 & 1 & 1 & 1 \\
\hline 9 & 1 & 0 & 1 & 1 & 1 & 1 & 1 & 0 & 1 & 1 & 1 & 1 & 1 & 1 & 0 & 1 & 1 & 1 & 1 & 1 & 1 & 1 & 1 \\
\hline $\begin{array}{l}1 \\
0\end{array}$ & 1 & 1 & 1 & 1 & 0 & 1 & 1 & 1 & 1 & 1 & 1 & 1 & 1 & 1 & 0 & 1 & 0 & 1 & 1 & 1 & 1 & 1 & 1 \\
\hline $\begin{array}{l}1 \\
1\end{array}$ & 1 & 1 & 1 & 1 & 0 & 1 & 1 & 1 & 1 & 1 & 1 & 1 & 1 & 1 & 1 & 1 & 0 & 0 & 1 & 1 & 1 & 1 & 1 \\
\hline $\begin{array}{l}1 \\
2\end{array}$ & 0 & 0 & 1 & 1 & 1 & 1 & 1 & 1 & 1 & 1 & 1 & 1 & 1 & 1 & 1 & 1 & 0 & 0 & 1 & 1 & 1 & 1 & 1 \\
\hline $\begin{array}{l}1 \\
3\end{array}$ & 1 & 0 & 1 & 1 & 0 & 0 & 1 & 1 & 1 & 1 & 1 & 1 & 1 & 1 & 1 & 1 & 0 & 0 & 1 & 1 & 1 & 1 & 1 \\
\hline $\begin{array}{l}1 \\
4\end{array}$ & 1 & 0 & 1 & 1 & 0 & 0 & 1 & 1 & 1 & 1 & 1 & 1 & 1 & 1 & 1 & 1 & 0 & 0 & 1 & 1 & 1 & 1 & 1 \\
\hline $\begin{array}{l}1 \\
5\end{array}$ & 1 & 1 & 1 & 0 & 0 & 1 & 1 & 1 & 1 & 0 & 1 & 1 & 1 & 1 & 1 & 1 & 0 & 0 & 1 & 1 & 1 & 1 & 1 \\
\hline $\begin{array}{l}1 \\
6\end{array}$ & 0 & 0 & 1 & 1 & 0 & 0 & 0 & 1 & 1 & 0 & 1 & 1 & 1 & 1 & 1 & 1 & 0 & 0 & 1 & 1 & 1 & 1 & 1 \\
\hline $\begin{array}{l}1 \\
7\end{array}$ & 1 & 1 & 1 & 1 & 1 & 1 & 1 & 1 & 1 & 1 & 1 & 1 & 1 & 1 & 1 & 1 & 1 & 0 & 1 & 1 & 1 & 1 & 0 \\
\hline $\begin{array}{l}1 \\
8\end{array}$ & 1 & 0 & 1 & 1 & 1 & 1 & 0 & 0 & 1 & 1 & 1 & 1 & 1 & 1 & 1 & 1 & 1 & 0 & 1 & 1 & 1 & 1 & 1 \\
\hline $\begin{array}{l}1 \\
9\end{array}$ & 1 & 1 & 1 & 1 & 1 & 0 & 1 & 1 & 1 & 0 & 1 & 1 & 1 & 1 & 1 & 1 & 1 & 1 & 1 & 1 & 1 & 1 & 1 \\
\hline $\begin{array}{l}2 \\
0 \\
\end{array}$ & 1 & 0 & 1 & 1 & 1 & 1 & 1 & 0 & 1 & 1 & 1 & 1 & 1 & 1 & 1 & 1 & 1 & 1 & 1 & 1 & 1 & 1 & 0 \\
\hline $\begin{array}{l}2 \\
1 \\
\end{array}$ & 1 & 0 & 1 & 1 & 1 & 1 & 1 & 1 & 1 & 0 & 1 & 1 & 1 & 1 & 1 & 1 & 1 & 1 & 1 & 1 & 1 & 1 & 1 \\
\hline $\begin{array}{l}2 \\
2\end{array}$ & 1 & 0 & 1 & 1 & 0 & 1 & 1 & 1 & 1 & 0 & 1 & 1 & 1 & 1 & 0 & 1 & 1 & 1 & 1 & 1 & 1 & 1 & 1 \\
\hline $\begin{array}{l}2 \\
3 \\
\end{array}$ & 1 & 1 & 1 & 1 & 0 & 1 & 1 & 1 & 1 & 1 & 1 & 1 & 1 & 1 & 0 & 1 & 1 & 1 & 1 & 1 & 1 & 1 & 1 \\
\hline $\begin{array}{l}2 \\
4 \\
\end{array}$ & 1 & 0 & 1 & 1 & 1 & 1 & 1 & 1 & 1 & 1 & 1 & 1 & 1 & 1 & 1 & 1 & 1 & 1 & 1 & 1 & 1 & 1 & 1 \\
\hline
\end{tabular}




\begin{tabular}{|c|c|c|c|c|c|c|c|c|c|c|c|c|c|c|c|c|c|c|c|c|c|c|c|c|}
\hline $\begin{array}{l}2 \\
5\end{array}$ & 0 & 0 & 1 & 1 & 1 & 1 & 1 & 1 & 1 & 1 & 1 & 1 & 1 & 1 & 1 & 1 & 1 & 1 & & & & & & 1 \\
\hline $\begin{array}{l}2 \\
6\end{array}$ & 1 & 1 & 1 & 1 & 1 & 1 & 1 & 1 & 1 & 1 & 1 & 1 & 1 & 0 & 1 & 1 & 1 & 1 & & & & & 1 & 1 \\
\hline $\begin{array}{l}2 \\
7\end{array}$ & 1 & 1 & 1 & 1 & 1 & 1 & 1 & 1 & 1 & 1 & 1 & 1 & 1 & 0 & 1 & 1 & 1 & 1 & & & & & 1 & 1 \\
\hline $\begin{array}{l}2 \\
8\end{array}$ & 1 & 1 & 1 & 1 & 1 & 0 & 1 & 1 & 1 & 1 & 1 & 1 & 1 & 1 & 1 & 1 & 1 & 1 & & & & & 1 & 1 \\
\hline $\begin{array}{l}2 \\
9\end{array}$ & 1 & 1 & 1 & 1 & 1 & 0 & 1 & 0 & 1 & 1 & 1 & 1 & 1 & 1 & 1 & 1 & 1 & 1 & & & & & 1 & 0 \\
\hline $\begin{array}{l}3 \\
0\end{array}$ & 1 & 1 & 1 & 1 & 1 & 0 & 1 & 1 & 1 & 1 & 1 & 1 & 1 & 1 & 1 & 1 & 0 & 1 & & & & & 1 & 0 \\
\hline $\begin{array}{l}3 \\
1\end{array}$ & 1 & 1 & 1 & 1 & 1 & 0 & 1 & 0 & 1 & 1 & 1 & 1 & 1 & 1 & 1 & 1 & 0 & 1 & & & & & 1 & 1 \\
\hline $\begin{array}{l}3 \\
2\end{array}$ & 1 & 1 & 1 & 1 & 1 & 0 & 1 & 1 & 1 & 0 & 1 & 1 & 1 & 1 & 1 & 1 & 0 & 1 & & & & & 1 & 1 \\
\hline $\begin{array}{l}3 \\
3\end{array}$ & 1 & 1 & 1 & 1 & 1 & 0 & 1 & $\overline{0}$ & 1 & 1 & 1 & 1 & 1 & 1 & 0 & 1 & 1 & 1 & & & & & 1 & 1 \\
\hline $\begin{array}{l}3 \\
4\end{array}$ & 1 & 1 & 1 & 1 & 1 & 1 & 1 & 1 & 1 & 0 & 1 & 1 & 1 & 1 & 0 & 1 & 1 & 1 & & & & & 1 & 0 \\
\hline $\begin{array}{l}3 \\
5\end{array}$ & 1 & 0 & 1 & 1 & 1 & 1 & 1 & 1 & 1 & 0 & 1 & 1 & 1 & 1 & 0 & 1 & 1 & 1 & & & & & 1 & 1 \\
\hline $\begin{array}{l}3 \\
6\end{array}$ & 1 & 0 & 1 & 1 & 1 & 1 & 1 & 1 & 1 & 0 & 1 & 1 & 1 & 1 & 0 & 1 & 1 & 1 & & & & & 1 & 1 \\
\hline $\begin{array}{l}3 \\
7\end{array}$ & 1 & 0 & 1 & 1 & 1 & 1 & 1 & 1 & 1 & 0 & 1 & 1 & 1 & 1 & 1 & 1 & 1 & 1 & & & & & 1 & 1 \\
\hline $\begin{array}{l}3 \\
8\end{array}$ & 1 & 0 & 1 & 1 & 1 & 1 & 1 & 1 & 1 & 1 & 1 & 1 & 1 & 1 & 1 & 1 & 1 & 1 & & & & & 1 & 1 \\
\hline $\begin{array}{l}3 \\
9\end{array}$ & 1 & 1 & 1 & 1 & 1 & 0 & 1 & 1 & 1 & 1 & 1 & 1 & 1 & 1 & 0 & 1 & 1 & 1 & & & & & 1 & 1 \\
\hline $\begin{array}{l}4 \\
0\end{array}$ & 1 & 0 & 1 & 1 & 0 & 1 & 1 & 1 & 1 & 1 & 1 & 1 & 1 & 1 & 0 & 1 & 1 & 1 & & & & & 1 & 1 \\
\hline $\begin{array}{l}4 \\
1\end{array}$ & 1 & 1 & 1 & 1 & 0 & 0 & 1 & 1 & 1 & 1 & 1 & 1 & 1 & 1 & 1 & 1 & 1 & 1 & & & & & 1 & 1 \\
\hline $\begin{array}{l}4 \\
2\end{array}$ & 1 & 0 & 1 & 1 & 1 & 0 & 1 & 0 & 1 & 1 & 1 & 1 & 1 & 1 & 1 & 1 & 1 & 1 & & & & & 1 & 1 \\
\hline $\begin{array}{l}4 \\
3 \\
\end{array}$ & 1 & 0 & 1 & 1 & 1 & 0 & 1 & 0 & 1 & 1 & 1 & 1 & 1 & 1 & 1 & 1 & 1 & 1 & & & & & 1 & 1 \\
\hline $\begin{array}{l}4 \\
4\end{array}$ & 1 & 1 & 1 & 1 & 1 & 1 & 1 & 1 & 1 & 1 & 1 & 1 & 1 & 1 & 1 & 1 & 1 & 1 & & & & & 1 & 1 \\
\hline $\begin{array}{l}4 \\
5\end{array}$ & 1 & 1 & 1 & 1 & 1 & 1 & 1 & 0 & 1 & 1 & 1 & 1 & 1 & 1 & 1 & 1 & 1 & 1 & & & & & 1 & 0 \\
\hline $\begin{array}{l}4 \\
6 \\
\end{array}$ & 1 & 0 & 1 & 1 & 1 & 0 & 1 & 1 & 1 & 1 & 1 & 1 & 1 & 1 & 1 & 1 & 1 & 1 & & & & & 1 & 1 \\
\hline $\begin{array}{l}4 \\
7\end{array}$ & 1 & 1 & 1 & 1 & 1 & 0 & 1 & 1 & 1 & 0 & 1 & 1 & 1 & 1 & 1 & 1 & 1 & 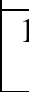 & & & & & 1 & 1 \\
\hline $\begin{array}{l}4 \\
8\end{array}$ & 1 & 1 & 1 & 1 & 1 & 0 & 1 & 1 & 1 & 0 & 1 & 1 & 1 & 1 & 1 & 1 & 1 & 1 & & & & & 1 & 1 \\
\hline $\begin{array}{l}4 \\
9\end{array}$ & 1 & 1 & 1 & 1 & 1 & 0 & 1 & 0 & 1 & 0 & 1 & 1 & 1 & 1 & 1 & 1 & 1 & 1 & & & & & 1 & 1 \\
\hline $\begin{array}{l}5 \\
0\end{array}$ & 1 & 0 & 1 & 1 & 1 & 0 & 1 & 1 & 1 & 0 & 1 & 1 & 1 & 1 & 1 & 1 & 0 & 0 & & & & & 1 & 1 \\
\hline $\begin{array}{l}5 \\
1\end{array}$ & 0 & 1 & 1 & 1 & 1 & 0 & 1 & 1 & 1 & 0 & 1 & 1 & 1 & 1 & 1 & 1 & 0 & ( & & & & & 1 & 0 \\
\hline
\end{tabular}




\begin{tabular}{|c|c|c|c|c|c|c|c|c|c|c|c|c|c|c|c|c|c|c|c|c|c|c|c|c|}
\hline $\begin{array}{l}5 \\
2\end{array}$ & 1 & 1 & 1 & 1 & 1 & 1 & 1 & 1 & 1 & 1 & 1 & 1 & 1 & 1 & 1 & 1 & 0 & 0 & & & & & 1 & 1 \\
\hline $\begin{array}{l}5 \\
3\end{array}$ & 1 & 1 & 1 & 1 & 1 & 0 & 1 & 1 & 1 & 1 & 1 & 1 & 1 & 1 & 1 & 1 & 0 & 0 & & & & & 1 & 1 \\
\hline $\begin{array}{l}5 \\
4\end{array}$ & 1 & 0 & 1 & 1 & 0 & 1 & 1 & 1 & 1 & 1 & 1 & 1 & 1 & 1 & 0 & 1 & 0 & 0 & & & & & 1 & 0 \\
\hline $\begin{array}{l}5 \\
5\end{array}$ & 1 & 0 & 1 & 1 & 1 & 0 & 1 & 1 & 1 & 1 & 1 & 1 & 1 & 1 & 0 & 1 & 0 & 0 & & & & & 1 & 1 \\
\hline $\begin{array}{l}5 \\
6\end{array}$ & 1 & 1 & 1 & 1 & 0 & 1 & 1 & 0 & 1 & 1 & 1 & 1 & 1 & 1 & 0 & 1 & 0 & 0 & & & & & 1 & 1 \\
\hline $\begin{array}{l}5 \\
7\end{array}$ & 1 & 1 & 1 & 1 & 1 & 0 & 1 & 1 & 1 & 1 & 1 & 1 & 1 & 1 & 1 & 1 & 0 & 0 & & & & & 1 & 1 \\
\hline $\begin{array}{l}5 \\
8\end{array}$ & 1 & 1 & 1 & 1 & 1 & 1 & 1 & 0 & 1 & 1 & 1 & 1 & 1 & 1 & 1 & 1 & 0 & 0 & & & & & 1 & 1 \\
\hline $\begin{array}{l}5 \\
9\end{array}$ & 1 & 1 & 1 & 1 & 1 & 0 & 1 & 1 & 1 & 1 & 1 & 1 & 1 & 1 & 1 & 1 & 0 & 0 & & & & & 1 & 1 \\
\hline $\begin{array}{l}6 \\
0\end{array}$ & 1 & 0 & 1 & 1 & 1 & 1 & 1 & 1 & 1 & 1 & 1 & 1 & 1 & 1 & 1 & 1 & 1 & 1 & & & & & 1 & 1 \\
\hline $\begin{array}{l}6 \\
1\end{array}$ & 0 & 0 & 1 & 1 & 1 & 0 & 1 & 0 & 1 & 0 & 1 & 1 & 1 & 1 & 1 & 1 & 1 & 1 & & & & & 1 & 1 \\
\hline $\begin{array}{l}6 \\
2\end{array}$ & 1 & 1 & 1 & 1 & 1 & 1 & 1 & 1 & 1 & 0 & 1 & 1 & 1 & 1 & 1 & 1 & 1 & 1 & & & & & 1 & 1 \\
\hline $\begin{array}{l}6 \\
3\end{array}$ & 1 & 0 & 1 & 1 & 1 & 0 & 1 & 0 & 1 & 1 & 1 & 1 & 1 & 0 & 1 & 1 & 1 & 1 & & & & & 1 & 1 \\
\hline $\begin{array}{l}6 \\
4\end{array}$ & 1 & 0 & 1 & 1 & 1 & 1 & 1 & 1 & 1 & 1 & 1 & 1 & 1 & 0 & 1 & 1 & 1 & 1 & & & & & 1 & 1 \\
\hline $\begin{array}{l}6 \\
5\end{array}$ & 1 & 1 & 1 & 1 & 1 & 0 & 1 & 1 & 1 & 0 & 1 & 1 & 1 & 1 & 0 & 1 & 1 & 1 & & & & & 1 & 0 \\
\hline $\begin{array}{l}6 \\
6 \\
\end{array}$ & 1 & 1 & 1 & 1 & 1 & 1 & 1 & 1 & 1 & 0 & 1 & 1 & 1 & 1 & 0 & 1 & 1 & 1 & & & & & 1 & 1 \\
\hline $\begin{array}{l}6 \\
7\end{array}$ & 1 & 1 & 1 & 1 & 1 & 0 & 1 & 1 & 1 & 1 & 1 & 1 & 1 & 1 & 0 & 1 & 1 & 1 & & & & & 1 & 1 \\
\hline $\begin{array}{l}6 \\
8\end{array}$ & 1 & 0 & 1 & 1 & 1 & 1 & 1 & 1 & 1 & 1 & 1 & 1 & 1 & 0 & 1 & 1 & 1 & 1 & & & & & 1 & 0 \\
\hline $\begin{array}{l}6 \\
9 \\
\end{array}$ & 1 & 0 & 1 & 1 & 1 & 1 & 1 & 0 & 1 & 0 & 1 & 1 & 1 & 0 & 1 & 1 & 1 & 1 & & & & & 1 & 1 \\
\hline $\begin{array}{l}7 \\
0\end{array}$ & 1 & 0 & 1 & 1 & 1 & 1 & 1 & 0 & 1 & 1 & 1 & 1 & 1 & 1 & 1 & 1 & 0 & 0 & & & & & 1 & 1 \\
\hline $\begin{array}{l}7 \\
1\end{array}$ & 1 & 0 & 1 & 1 & 1 & 1 & 1 & 1 & 1 & 1 & 1 & 1 & 1 & 1 & 1 & 1 & 0 & 0 & & & & & 1 & 1 \\
\hline $\begin{array}{l}7 \\
2\end{array}$ & 1 & 0 & 1 & 1 & 1 & 1 & 1 & 0 & 1 & 0 & 1 & 1 & 1 & 1 & 1 & 1 & 0 & 0 & & & & & 1 & 1 \\
\hline $\begin{array}{l}7 \\
3\end{array}$ & 1 & 1 & 1 & 1 & 1 & 1 & 1 & 1 & 1 & 0 & 1 & 1 & 1 & 1 & 1 & 1 & 0 & 0 & & & & & 1 & 1 \\
\hline $\begin{array}{l}7 \\
4\end{array}$ & 1 & 1 & 1 & 1 & 1 & 1 & 1 & 1 & 1 & 1 & 1 & 1 & 1 & 1 & 1 & 1 & 0 & 0 & & & & & 1 & 1 \\
\hline $\begin{array}{l}7 \\
5\end{array}$ & 1 & 1 & 1 & 1 & 1 & 1 & 1 & 1 & 1 & 1 & 1 & 1 & 1 & 1 & 1 & 1 & 0 & 0 & & & & & 1 & 1 \\
\hline $\begin{array}{l}7 \\
6\end{array}$ & 1 & 0 & 1 & 1 & 1 & 1 & 1 & 1 & 1 & 0 & 1 & 1 & 1 & 1 & 1 & 1 & 0 & 0 & & & & & 1 & 1 \\
\hline $\begin{array}{l}7 \\
7\end{array}$ & 1 & 0 & 1 & 1 & 1 & 1 & 1 & 1 & 1 & 1 & 1 & 1 & 1 & 1 & 1 & 1 & 0 & 0 & & & & & 1 & 1 \\
\hline $\begin{array}{l}7 \\
8\end{array}$ & 1 & 0 & 1 & 1 & 1 & 1 & 1 & 1 & 1 & 1 & 1 & 1 & 1 & 1 & 1 & 1 & 0 & 0 & & & & & 1 & 0 \\
\hline
\end{tabular}




\begin{tabular}{|c|c|c|c|c|c|c|c|c|c|c|c|c|c|c|c|c|c|c|c|c|c|c|c|}
\hline $\begin{array}{l}7 \\
9\end{array}$ & 1 & 0 & 1 & 1 & 1 & 1 & 1 & 1 & 1 & 0 & 1 & 1 & 1 & 1 & 1 & 1 & 0 & 1 & 1 & 1 & 1 & 1 & 0 \\
\hline $\begin{array}{l}8 \\
0\end{array}$ & 0 & 0 & 1 & 1 & 1 & 1 & 1 & 1 & 1 & 1 & 1 & 1 & 1 & 1 & 1 & 1 & 1 & 1 & 1 & 1 & 1 & 1 & 1 \\
\hline $\begin{array}{l}8 \\
1\end{array}$ & 0 & 0 & 1 & 1 & 1 & 1 & 1 & 1 & 1 & 1 & 1 & 1 & 1 & 1 & 1 & 1 & 1 & 1 & 1 & 1 & 1 & 1 & 1 \\
\hline $\begin{array}{l}8 \\
2\end{array}$ & 1 & 1 & 1 & 1 & 1 & 1 & 0 & 1 & 1 & 0 & 1 & 1 & 1 & 1 & 1 & 1 & 1 & 1 & 1 & 1 & 1 & 1 & 1 \\
\hline $\begin{array}{l}8 \\
3\end{array}$ & 1 & 1 & 1 & 1 & 1 & 1 & 1 & 1 & 1 & 1 & 1 & 1 & 1 & 0 & 1 & 1 & 1 & 1 & 1 & 1 & 1 & 1 & 1 \\
\hline $\begin{array}{l}8 \\
4\end{array}$ & 1 & 1 & 1 & 1 & 1 & 1 & 0 & 1 & 1 & 1 & 1 & 1 & 1 & 0 & 1 & 1 & 1 & 1 & 1 & 1 & 1 & 1 & 1 \\
\hline $\begin{array}{l}8 \\
5\end{array}$ & 1 & 1 & 1 & 1 & 1 & 1 & 1 & 1 & 1 & 1 & 1 & 1 & 1 & 1 & 1 & 1 & 1 & 1 & 1 & 1 & 1 & 1 & 1 \\
\hline $\begin{array}{l}8 \\
6 \\
\end{array}$ & 1 & 0 & 1 & 1 & 1 & 0 & 1 & 0 & 1 & 1 & 1 & 1 & 1 & 1 & 1 & 1 & 1 & 1 & 1 & 1 & 1 & 1 & 1 \\
\hline $\begin{array}{l}8 \\
7\end{array}$ & 1 & 0 & 1 & 1 & 1 & 1 & 1 & 1 & 1 & 1 & 1 & 1 & 1 & 1 & 1 & 1 & 1 & 1 & 1 & 1 & 1 & 1 & 1 \\
\hline $\begin{array}{l}8 \\
8\end{array}$ & 1 & 0 & 1 & 1 & 1 & 0 & 1 & 1 & 1 & 1 & 1 & 1 & 1 & 1 & 1 & 1 & 1 & 1 & 1 & 1 & 1 & 1 & 1 \\
\hline $\begin{array}{l}8 \\
9\end{array}$ & 1 & 0 & 1 & 1 & 1 & 1 & 1 & 0 & 1 & 1 & 1 & 1 & 1 & 1 & 1 & 1 & 1 & 1 & 1 & 1 & 1 & 1 & 1 \\
\hline $\begin{array}{l}9 \\
0\end{array}$ & 1 & 1 & 1 & 1 & 1 & 1 & 1 & 1 & 1 & 0 & 1 & 1 & 1 & 1 & 1 & 1 & 1 & 1 & 1 & 1 & 1 & 1 & 1 \\
\hline $\begin{array}{l}9 \\
1\end{array}$ & 1 & 1 & 1 & 1 & 0 & 1 & 1 & 1 & 1 & 1 & 1 & 1 & 1 & 1 & 1 & 1 & 1 & 1 & 1 & 1 & 1 & 1 & 1 \\
\hline $\begin{array}{l}9 \\
2\end{array}$ & 1 & 1 & 1 & 1 & 0 & 1 & 1 & 1 & 1 & 0 & 1 & 1 & 1 & 1 & 1 & 1 & 1 & 1 & 1 & 1 & 1 & 1 & 0 \\
\hline $\begin{array}{l}9 \\
3\end{array}$ & 1 & 0 & 1 & 1 & 1 & 1 & 1 & 1 & 1 & 0 & 1 & 1 & 1 & 1 & 1 & 1 & 1 & 1 & 1 & 1 & 1 & 1 & 1 \\
\hline $\begin{array}{l}9 \\
4\end{array}$ & 1 & 0 & 1 & 1 & 1 & 1 & 1 & 0 & 1 & 1 & 1 & 1 & 1 & 1 & 1 & 1 & 1 & 1 & 1 & 1 & 1 & 1 & 1 \\
\hline $\begin{array}{l}9 \\
5 \\
\end{array}$ & 1 & 0 & 1 & 1 & 1 & 1 & 1 & 1 & 1 & 1 & 1 & 1 & 1 & 1 & 1 & 1 & 1 & 1 & 1 & 1 & 1 & 1 & 1 \\
\hline $\begin{array}{l}9 \\
6\end{array}$ & 1 & 0 & 1 & 1 & 1 & 1 & 1 & 1 & 1 & 0 & 1 & 1 & 1 & 1 & 1 & 1 & 1 & 1 & 1 & 1 & 1 & 1 & 1 \\
\hline $\begin{array}{l}9 \\
7\end{array}$ & 1 & 0 & 1 & 1 & 1 & 1 & 1 & 1 & 1 & 0 & 1 & 1 & 1 & 1 & 1 & 1 & 1 & 1 & 1 & 1 & 1 & 1 & 1 \\
\hline $\begin{array}{l}9 \\
8\end{array}$ & 1 & 1 & 1 & 1 & 1 & 1 & 1 & 1 & 1 & 0 & 1 & 1 & 1 & 1 & 0 & 1 & 1 & 1 & 1 & 1 & 1 & 1 & 1 \\
\hline $\begin{array}{l}9 \\
9\end{array}$ & 1 & 1 & 1 & 1 & 1 & 1 & 1 & 0 & 1 & 0 & 1 & 1 & 1 & 1 & 1 & 1 & 1 & 1 & 1 & 1 & 1 & 1 & 1 \\
\hline $\begin{array}{l} \\
0 \\
0\end{array}$ & 1 & 1 & 1 & 1 & 1 & 1 & 0 & 0 & 1 & 1 & 1 & 1 & 1 & 1 & 1 & 1 & 1 & 1 & 1 & 1 & 1 & 1 & 1 \\
\hline $\begin{array}{l}1 \\
0 \\
1\end{array}$ & 1 & 1 & 1 & 1 & 1 & 1 & 1 & 0 & 0 & 1 & 1 & 1 & 1 & 1 & 1 & 1 & 1 & 1 & 1 & 1 & 1 & 1 & 1 \\
\hline $\begin{array}{l}1 \\
0 \\
2\end{array}$ & 1 & 1 & 1 & 1 & 1 & 1 & 0 & 1 & 0 & 1 & 1 & 1 & 1 & 1 & 1 & 1 & 1 & 1 & 1 & 1 & 1 & 1 & 1 \\
\hline $\begin{array}{l}1 \\
0 \\
3\end{array}$ & 1 & 0 & 1 & 1 & 1 & 1 & 1 & 1 & 1 & 1 & 1 & 1 & 1 & 1 & 1 & 1 & 1 & 1 & 1 & 1 & 1 & 1 & 0 \\
\hline
\end{tabular}




\begin{tabular}{|c|c|c|c|c|c|c|c|c|c|c|c|c|c|c|c|c|c|c|c|c|c|c|c|c|}
\hline $\begin{array}{l}1 \\
0 \\
4\end{array}$ & 1 & 0 & 1 & 1 & 1 & 1 & 1 & 1 & 1 & 1 & 1 & 1 & 1 & 1 & 1 & 1 & 1 & 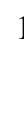 & 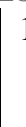 & 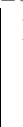 & & & 1 & 1 \\
\hline $\begin{array}{l}1 \\
0 \\
5\end{array}$ & 1 & 1 & 1 & 1 & 1 & 1 & 1 & 1 & 1 & 1 & 1 & 1 & 1 & 1 & 0 & 1 & 1 & 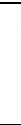 & 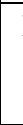 & 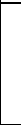 & & & 1 & 1 \\
\hline $\begin{array}{l}1 \\
0 \\
6\end{array}$ & 1 & 1 & 1 & 1 & 0 & 1 & 1 & 1 & 1 & 1 & 1 & 1 & 1 & 1 & 1 & 1 & 1 & 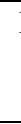 & 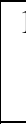 & 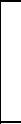 & & & 1 & 0 \\
\hline $\begin{array}{l}1 \\
0 \\
7 \\
\end{array}$ & 1 & 1 & 1 & 1 & 1 & 1 & 1 & 1 & 1 & 1 & 1 & 1 & 1 & 1 & 1 & 1 & 1 & 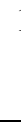 & 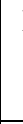 & 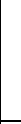 & & & 1 & 1 \\
\hline $\begin{array}{l}1 \\
0 \\
8 \\
\end{array}$ & 1 & 1 & 1 & 1 & 1 & 1 & 1 & 1 & 0 & 1 & 1 & 1 & 1 & 1 & 1 & 1 & 1 & 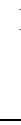 & 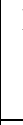 & & & & 1 & 1 \\
\hline $\begin{array}{l}1 \\
0 \\
9\end{array}$ & 1 & 0 & 1 & 1 & 1 & 1 & 1 & 1 & 0 & 1 & 1 & 1 & 1 & 1 & 1 & 1 & 1 & 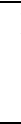 & 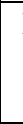 & 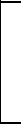 & & & 1 & 0 \\
\hline $\begin{array}{l}1 \\
1 \\
0 \\
\end{array}$ & 1 & 1 & 1 & 1 & 1 & 1 & 1 & 0 & 1 & 0 & 1 & 1 & 1 & 1 & 1 & 1 & 1 & 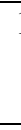 & 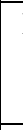 & 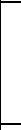 & & & 1 & 1 \\
\hline $\begin{array}{l}1 \\
1 \\
1\end{array}$ & 1 & 0 & 1 & 1 & 1 & 1 & 1 & 0 & 1 & 0 & 1 & 1 & 1 & 1 & 1 & 1 & 1 & 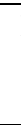 & 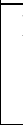 & & & & 1 & 1 \\
\hline $\begin{array}{l}1 \\
1 \\
2 \\
\end{array}$ & 1 & 0 & 1 & 1 & 1 & 1 & 1 & 0 & 1 & 0 & 1 & 1 & 1 & 1 & 1 & 1 & 1 & 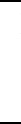 & 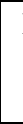 & & & & 1 & 1 \\
\hline $\begin{array}{l}1 \\
1 \\
3 \\
\end{array}$ & 1 & 1 & 1 & 1 & 1 & 1 & 1 & 1 & 1 & 0 & 1 & 1 & 1 & 1 & 1 & 1 & 1 & 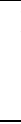 & 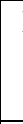 & & & & 1 & 1 \\
\hline $\begin{array}{l}1 \\
1 \\
4\end{array}$ & 1 & 1 & 1 & 1 & 1 & 1 & 1 & 1 & 1 & 1 & 1 & 1 & 1 & 1 & 1 & 1 & 1 & 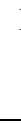 & 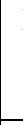 & & & & 1 & 0 \\
\hline $\begin{array}{l}1 \\
1 \\
5 \\
\end{array}$ & 1 & 1 & 1 & 1 & 1 & 1 & 1 & 1 & 1 & 1 & 1 & 1 & 1 & 1 & 1 & 1 & 1 & 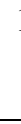 & 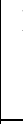 & & & & 1 & 1 \\
\hline $\begin{array}{l}1 \\
1 \\
6 \\
\end{array}$ & 1 & 0 & 1 & 1 & 0 & 1 & 1 & 1 & 1 & 1 & 1 & 1 & 1 & 0 & 1 & 1 & 1 & 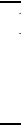 & 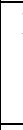 & & & & 1 & 1 \\
\hline $\begin{array}{l}1 \\
1 \\
7 \\
\end{array}$ & 1 & 0 & 1 & 1 & 0 & 1 & 0 & 1 & 1 & 1 & 1 & 1 & 1 & 0 & 1 & 1 & 1 & 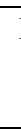 & 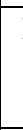 & & & & 1 & 0 \\
\hline $\begin{array}{l}1 \\
1 \\
8 \\
\end{array}$ & 1 & 1 & 1 & 1 & 1 & 1 & 0 & 0 & 1 & 1 & 1 & 1 & 1 & 1 & 1 & 1 & 1 & 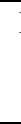 & 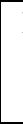 & & & & 1 & 1 \\
\hline $\begin{array}{l}1 \\
1 \\
9\end{array}$ & 1 & 1 & 1 & 1 & 1 & 1 & 1 & 0 & 1 & 1 & 1 & 1 & 1 & 1 & 1 & 1 & 1 & 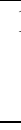 & 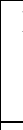 & & & & 1 & 1 \\
\hline $\begin{array}{l}1 \\
2 \\
0 \\
\end{array}$ & 1 & 1 & 1 & 1 & 1 & 1 & 1 & 1 & 1 & 1 & 1 & 1 & 1 & 1 & 1 & 1 & 1 & 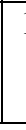 & 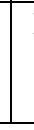 & & & & 1 & 1 \\
\hline
\end{tabular}




\section{References}

[1] Iravani M, Zarean E, Janghorbani M and Bahrami M. Women's needs and expectations during normal labor and delivery. Journal of education and health promotion. Feb 23, 2015; 4:(6). doi : 10.4103/22779531151885.

[2] Mohammad K , Shaban I, Homer C and Creedy D. Women's satisfaction with hospital-based intrapartum care: A Jordanian study. International Journal of Nursing and Midwifery. July 2014; 6(3): p.32-39.doi:10.5897/IJNM2014.0127. available at http://www.academicjournals.org/IJNM.

[3] Negron R, Martin A, Almog M, Balbierz A, Elizabeth A and Howell. Social support during the postpartum period: Mothers' views on needs, expectations, and mobilization of support. Matern Child Health J .2013 May; 17(4):616-623.doi:10.1007/s10995-012-1037-4.

[4] Zhang $X$ and Lu H. Childbirth expectations and correlates at the final stage of pregnancy in Chinese expectant parents.http://www.elsevier.com/journals/international journal-of-nursing-sciences/23520132.

[5] Abdel GR, Berggren V. Parturient Needs during Labor: Egyptian Women's Perspective toward Childbirth Experience, a Step toward an Excellence in Clinical Practice. Journal of Basic and Applied Science Research. 1(12), 2011, 2935-2943. Available at www.textroad.com

[6] Panda S, D'Sa J, Rao AC. Support needs of women in early labour. DOI:10.14302/2381-86X.jwrh15-672.1(2)15. Available at www.openaccessub.org.

[7] Iliadou M. Supporting women in labour. Health Science Journal. July-sep, 2012; 6(3):Available at www.hsj.gr.

[8] Pirdel M, Pirdel L.A comparison of women's expectations of labour and birth with the experiences in primiparas and multiparas with normal vaginal delivery. Journal of Kathmandu Medical College. JanMarch., 2015; 4(1):11.

[9] Lindberg I, Ohrling K, Christensson K. Expectations of postpartum care among pregnant women living in the north of Sweden. Available at International journal of Circumpolar Health. 2008;67:5.

*Corresponding author.

E-mail address: khanshikha16@gmail.com/smriti_mani@ yahoo.com 